\title{
The Vote Is Cast: The Effect of Corporate Governance on Shareholder Value
}

\author{
VICENTE CUÑAT, MIREIA GINE, and MARIA GUADALUPE*
}

\begin{abstract}
This paper investigates whether improvements in the firm's internal corporate governance create value for shareholders. We analyze the market reaction to governance proposals that pass or fail by a small margin of votes in annual meetings. This provides a clean causal estimate that deals with the endogeneity of internal governance rules. We find that passing a proposal leads to significant positive abnormal returns. Adopting one governance proposal increases shareholder value by $2.8 \%$. The market reaction is larger in firms with more antitakeover provisions, higher institutional ownership, and stronger investor activism for proposals sponsored by institutions. In addition, we find that acquisitions and capital expenditures decline and long-term performance improves.
\end{abstract}

CORPORATE GOVERNANCE PROVISIONS grant managers independence to manage the firm. However, they also insulate managers from the monitoring and control of shareholders. ${ }^{1}$ Establishing empirically how these provisions affect shareholder value and what type of shareholder rights have greater effects is essential for our understanding of the internal governance of firms. In practice, it is generally difficult to find a setting in which a firm's governance structure changes exogenously. As a result, the existing literature has generally not been able to provide causal estimates of the effect of these corporate governance provisions. ${ }^{2}$ Furthermore, the range of results in the

*Vicente Cuñat, London School of Economics; Mireia Gine, WRDS University of Pennsylvania and Public-Private Sector Research Center, IESE Business School; Maria Guadalupe, INSEAD, NBER, CEPR, and IZA. We are grateful to Ashwini Agrawal; Ann Bartel; Ken Chay; Jeff Coles; Jan Eeckhout; Ray Fisman; Laurie Hodrick; Denis Gromb; Raymond Lim; Marco Manacorda; Zacharias Sautner; David Yermack; and seminar participants at Brown University, Columbia Business School, the University of Edinburgh, Goethe University, LeBow College of Business Conference on Corporate Governance, the London School of Economics, University of Michigan, the New York University Paduano Seminar, and the University of Oregon for their helpful comments and suggestions. The usual disclaimer applies.

${ }^{1}$ See, for example, Shleifer and Vishny (1997), Becht, Bolton, and Röell (2005), Comment and Schwert (1995), Gompers, Ishii, and Metrick (2003), Bebchuck, Cohen, and Ferrell (2004), and Core, Guay, and Rusticus (2006).

${ }^{2}$ Prior research shows that legislative changes that affect external governance measures, such as state-level antitakeover legislation, increase managerial slack and reduce performance (Garvey and Hanka (1999), Bertrand and Mullainathan (2003), Giroud and Mueller (2010)). Internal governance arrangements, the ones developed by the firm itself, have been the subject of much research, but the evidence provided in these papers is mixed and, most importantly, based on correlations rather than on causal estimates. 
existing literature varies widely, from negative effects of increased shareholder rights (e.g., Comment and Schwert (1995), Kadyrzhanova and Rhodes-Kropf (2011)) to very large and positive effects on firm performance (e.g., Gompers, Ishii, and Metrick (2003), Bebchuck, Cohen, and Ferrell (2004)). Given the relevance of the question and the number of papers written on the topic, an analysis providing a causal estimate that is able to establish the sign and magnitude of the effect of changing governance structures seems of utmost importance. This paper provides an estimate that overcomes the limitations of the existing literature. In particular, we exploit the outcomes of votes on shareholder-sponsored governance proposals at annual meetings to provide a causal estimate of the effect of changes in the firm's internal corporate governance structure on shareholder value and managers' behavior. ${ }^{3}$

It is difficult to estimate the effect of changes in governance provisions on shareholder returns for primarily two reasons. First, the choice of governance structure and the type of provisions adopted by firms are arguably endogenous and correlated with other firm characteristics. Thus, comparing the returns of firms with different governance structures is likely to capture the effect of those unobserved characteristics rather than the effect of governance. Second, if investors know about the superior performance of better-governed firms, their knowledge should be incorporated into prices and we should not observe any systematic differences in abnormal returns. These problems are pervasive in the existing literature. To overcome these limitations, we need a setting in which governance rules are exogenously or "randomly" adopted and, at the same time, in which their adoption is not foreseen by the market and incorporated into returns.

We argue that a regression discontinuity design on the outcomes of shareholder proposals in annual meetings allows us to overcome the two limitations of standard regressions of stock market returns on governance provisions. This empirical strategy essentially compares the stock market's reaction to shareholder-sponsored governance proposals that pass by a small margin to those that fail by a small margin. For these close-call proposals, passing is akin to an independent random event (it is "locally" exogenous) and therefore uncorrelated with firm characteristics. Intuitively, the average characteristics of a firm in which a proposal passes with $50.1 \%$ of the votes are similar to those of a firm in which the proposal gathers only $49.9 \%$ and fails to pass. However, this small difference in the vote share leads to a discrete change in the probability of implementing a proposal. Empirically, the proposal that passes is 20.7\% more likely to be implemented (Ertimur, Ferri, and Stubben (2010)). Our estimate captures the effect of this discrete change in implementation at the majority threshold (the number of votes that determines whether a proposal passes). More importantly, this estimate does not incorporate any observed or

\footnotetext{
${ }^{3}$ Corporate governance provisions voted on in annual meetings include provisions that lower takeover barriers, regulate the independence of the board from management, define the voting rules in annual meetings, and decide on executive and board compensation.
} 
unobserved confounding factors as long as their effect is continuous around the threshold. We show that, indeed, for votes around the majority threshold, passing is uncorrelated with a large number of observed firm and meeting characteristics. Hence, by focusing on these proposals, we can plausibly estimate a causal effect.

In addition, it is precisely for these close-call proposals that the vote contains substantial information-switching from an unpredictable outcome to either pass or fail-that is not already fully incorporated in prices. Before the vote, and given the uncertainty inherent in the vote outcome, the market is unable to predict which close-call proposals will pass and which will fail. However, the distribution of prior expectations of proposals that ex post get a $49.9 \%$ vote share is, on average, very similar to the distribution of expectations of proposals that obtain a $50.1 \%$ vote share. Therefore, just before the election takes place, the expected return to the vote, which is already incorporated into prices, is very close for these two types of firms. After the vote, uncertainty is resolved since some proposals pass and others do not, and the price for each firm reacts correspondingly to incorporate the information. We adapt the regression discontinuity methodology to the analysis of stock returns in an event study. We present an analytical framework that shows how stock prices should react for each observed vote outcome and how one can recover the value of passing a provision from the outcome of votes around the majority threshold. We also discuss how the observed reaction varies with the probability of implementing a proposal and other information that may be contained in the vote outcome. This is, in a nutshell, the regression discontinuity design that allows us to obtain a clean estimate of the effect of shareholder-sponsored proposals.

Our data set includes all shareholder-sponsored governance proposals voted on in firms included in the S\&P 1500, plus another sample of 500 widely held firms between 1997 and 2007. This yields almost 4,000 proposals. We restrict ourselves to shareholder-sponsored proposals because, unlike managementsponsored ones, they cannot be removed strategically by the firm's management, and their vote distribution is not affected by selective withdrawal around the discontinuity (see Section III and Listokin (2008)). Given the structure of our data, we adopt the empirical dynamic regression discontinuity model proposed by Cellini, Ferreira, and Rothstein (2010), and we allow the result of the vote in any given annual meeting to affect future outcomes and the votes in future meetings. We also adapt this methodology to deal with multiple votes in one meeting.

The results show that, on the day of the vote, a shareholder governance proposal that passes yields an abnormal return of $1.3 \%$ relative to one that fails. The 1 -week cumulative return is $2.4 \%$. This price reaction is more pronounced for the set of antitakeover provisions included in the G-index developed by Gompers, Ishii, and Metrick (2003), suggesting that these provisions are important for governance (since Jensen (1986), it has been argued that takeover threats are an important form of managerial discipline). In particular, the effect is largely driven by proposals to eliminate classified boards and poison pills, 
which represent $68 \%$ of the G-Index proposals that fall around the majority threshold. We also find that other proposals, such as those increasing board independence, have a positive but weaker effect on returns. Finally, we find that the effect is stronger among firms with concentrated ownership, for those with a large number of antitakeover provisions in place, for those with high R\&D expenditures, for those with more shareholder proposals in the past, and for proposals made by institutional shareholders rather than by individuals.

However, the estimated excess return of passing a proposal is not necessarily the full expected increase in value from implementing the proposal. This is because the estimated excess return (the market response to the event) incorporates two probabilities: first, the change in the probability of implementing the proposal as a result of the vote, and second, the probability that passing the proposal may lead to other governance proposals being submitted and implemented in the future (dynamic effects). Using these estimated probabilities, we calculate that, for the firms in our sample, adopting a governance proposal increases shareholder value by $2.8 \%$. We estimate that two-thirds of the reaction corresponds to the contemporaneous implementation of proposals directly following the vote and one-third to dynamic effects. This is an economically sizeable effect, especially when we consider that firms often drop several provisions in subsequent meetings. Dropping 2.5 provisions (one standard deviation of the G-index in the sample) translates into a predicted increase in market value of $7 \%$, implying that the economic consequences of poor governance arrangements are nonnegligible.

Finally, we examine the real effects beyond the stock price reaction on the day of the vote. The regression discontinuity design allows us to study the effect of the new governance arrangements on variables such as acquisitions and capital expenditures, which have been used as proxies for empire building and potentially inefficient behavior (e.g., Bertrand and Mullainathan (2003), Gompers, Ishii, and Metrick (2003)). We find that acquisitions and capital expenditures fall as a result of passing corporate governance proposals. We also find evidence that firm value - as reflected by Tobin's $Q$ and the book-to-market ratio-increases in the years following the vote. We interpret these results as evidence that firms are operated differently as a result of their improved corporate governance structure, reflecting changes in managers' behavior. Finally, the effect that we identify pertains, by definition, only to firms that have observations around the discontinuity, which affects the degree to which one can extrapolate the results of our analysis to other firms. However, we show that firms with observations falling around the threshold are not very different from other firms that are subject to shareholder proposals and that $35 \%$ of the G-index proposals fall within 10 percentage points of the majority threshold. This suggests that our results can be directly generalizable to a sizeable set of firms, though not to all.

Our results can be interpreted as the causal effect of corporate governance on firm value. In contrast, the estimates in most preexisting studies may be biased because of the nonrandom nature of governance structures. For example, if better-run firms (e.g., firms where managers are already committed to generate 
value for shareholders) are likely to have both better governance and higher performance, this would cause regression coefficients to be biased upwards. Alternatively, if good governance is more likely to be in place when management is poor (e.g., management and good governance are substitutes), simple regression estimates would underestimate the causal effect of governance. Ultimately, the sign and magnitude of the biases is an empirical question. In addition, our approach explicitly deals with the fact that market returns incorporate investors' expectations. Core, Guay, and Rusticus (2006) emphasize that if governance provisions are observable and their influence is well understood, the effect of different levels of governance should already be incorporated in share prices. As such, we should not observe any permanent excess returns for different governance levels. Our paper extends this argument not only to levels, but also to predictable changes in governance. In fact, we show that there are no significant price reactions to votes that pass or fail by large margins, suggesting that the market had already factored them into the share price.

In their influential paper, Gompers, Ishii, and Metrick (2003) report average annual abnormal returns of $8.5 \%$ of going long on the so-called democratic portfolio and short on the dictatorship portfolio between 1990 and 1999. As Core, Guay, and Rusticus (2006) emphasize, however, with efficient markets these returns can only be justified if the market learned about the value of good governance precisely during this period. This estimate can also be tainted by endogeneity if governance structures are correlated with omitted variables. Our main estimates indicate that this learning process should have led to annual returns of around 2.6\%, a substantial yet much smaller effect than the Gompers, Ishii, and Metrick (2003) value. ${ }^{4}$ The rest of the effect could be attributed to the presence of endogeneity (and/or to the fact that we are studying a different sample period). Therefore, our results suggest that preexisting estimates are upward biased.

Besides establishing how much shareholder value is generated by increasing shareholder rights and improving corporate governance inside firms, our results imply that shareholder activism can create significant value. Improving democracy inside firms, so that shareholder proposals that fall short of the majority threshold pass, would be value-increasing. We are able to precisely quantify that value. Finally, our novel use of the regression discontinuity identification can be applied in other settings in which a discontinuity treatment is combined with an event study.

This paper is organized as follows. Section I describes the data and presents an analytical framework of how information on the stock price reaction to the outcome of governance votes that fall around the majority threshold allows us to recover the effect of governance proposals. Section II presents the empirical model used to identify this effect. Section III provides evidence on the regression discontinuity in shareholder votes as a quasi-experiment. Section IV presents the results, and Section V concludes.

\footnotetext{
${ }^{4} \mathrm{~A}$ less conservative estimate based on 1 -week cumulative returns can explain up to $5.1 \%$ of the abnormal return, which is still well below the Gompers, Ishii, and Metrick (2003) value.
} 


\section{Shareholder Votes and Abnormal Returns}

\section{A. Data Description}

We use data collected by Riskmetrics on shareholders' proposals from 1997 to 2007. ${ }^{5}$ Our sample includes all 3,984 shareholder proposals that Riskmetrics classifies as governance-related and that are included in the proxy statement for all S\&P 1500 companies, plus an additional 500 widely held firms (the Appendix shows the full list of proposals and how frequently each of them appears in the data). Riskmetrics provides data on the company name, the date of the annual meeting, the percentage of votes in favor of the proposal, the description of the type of proposal, and the proponent. ${ }^{6}$ Most shareholder proposals are presented as a recommendation to the board of directors-that is, the outcome of the vote is nonbinding. Ertimur, Ferri, and Stubben (2010) show that $31.1 \%$ of the shareholder proposals that pass are implemented, whereas only $3.2 \%$ of those not approved are implemented.

Riskmetrics classifies the proposals into 72 distinct types. While the effect of the different types of proposals is probably heterogeneous, we bundle them into broader categories due to the limited number of observations in each group. For descriptive purposes, we group governance proposals into six categories widely used in the literature: antitakeover proposals (G-index), compensation, voting, auditors, board structure, and other (see the Appendix). Panel A of Table I displays the frequency of governance proposals, the percent approved, and the average support over time. From 2003 onward, there is a significant increase in the number of proposals (over 400 per year), and around $30 \%$ of those are approved. Panel B also shows that G-index proposals obtained the highest levels of shareholder support and were approved in 53\% of the cases. Compensation proposals were approved in only $4.2 \%$ of the cases, board structure proposals in $8.8 \%$ of the cases, and voting proposals in $3.3 \%$ of the cases. For the empirical analysis, the difference in approval rates means that we have very few observations on compensation, board structure, or voting around the discontinuity, so we have to further pool all those proposals and analyze them together. The Appendix shows the number of proposals of each type falling

\footnotetext{
${ }^{5}$ Rule 14a-8 permits shareholders to submit proposals requesting that certain corporate matters be put to a vote at the company's next annual meeting. Proposals are submitted in advance and incorporated in the proxy material for the meeting. To be eligible to submit a proposal, a shareholder must be a beneficial owner of at least $1 \%$ or $\$ 2,000$ in market value of securities entitled to vote, have owned these securities for at least 1 year, and continue to own them through the date of the meeting. The vote outcome is not revealed until the actual day of the meeting.

${ }^{6}$ We check that all the proposals go in the direction of increasing shareholder rights and control, or improving alignment. We also use a second Riskmetrics data set with information on whether the majority is computed out of votes cast or outstanding, and on the majority threshold. Most proposals have a 50\% majority threshold, three had a $66.7 \%$ threshold, three had a $70 \%$ threshold, and four had an $80 \%$ threshold. We also used this data set to check that the vote was correctly recorded. In the cases where we find discrepancies between the two data sets, we look at the company statements.
} 
Table I

\section{Shareholder Governance Proposals}

Panel A displays the frequency, approval percentage, and average support over time of governance proposals. Data are collected by Riskmetrics on all shareholder governance proposals from 1997 to 2007 for all S\&P 1500 companies plus an additional 500 widely held firms. The threshold for approval is $50 \%$ for all but 10 observations. We take into account the different threshold rules across proposals and firms for computing the percentage of approved proposals. Panel B classifies governance proposals by type.

\begin{tabular}{|c|c|c|c|c|c|}
\hline \multicolumn{6}{|c|}{ Panel A: Shareholder Proposal Summary Statistics } \\
\hline Year & $\begin{array}{l}\text { Shareholder } \\
\text { Proposals }\end{array}$ & $\begin{array}{l}\text { Approved } \\
\text { Proposals }\end{array}$ & $\begin{array}{c}\text { Percentage } \\
\text { Approved } \\
\text { Proposals }\end{array}$ & $\begin{array}{c}\text { Average Vote } \\
\text { Outcome }\end{array}$ & $\begin{array}{l}\text { Std. Dev. Vote } \\
\text { Outcome }\end{array}$ \\
\hline 1997 & 292 & 29 & $9.90 \%$ & $23.13 \%$ & 17.46 \\
\hline 1998 & 272 & 37 & $13.66 \%$ & $26.29 \%$ & 19.11 \\
\hline 1999 & 310 & 58 & $18.70 \%$ & $28.60 \%$ & 21.84 \\
\hline 2000 & 272 & 70 & $25.00 \%$ & $30.95 \%$ & 23 \\
\hline 2001 & 277 & 67 & $24.00 \%$ & $30.03 \%$ & 22.21 \\
\hline 2002 & 297 & 100 & $33.60 \%$ & $36.61 \%$ & 23.38 \\
\hline 2003 & 479 & 166 & $34.60 \%$ & $37.50 \%$ & 23.27 \\
\hline 2004 & 451 & 126 & $27.00 \%$ & $33.12 \%$ & 25.05 \\
\hline 2005 & 417 & 124 & $29.70 \%$ & $37.17 \%$ & 23.99 \\
\hline 2006 & 450 & 143 & $31.70 \%$ & $40.87 \%$ & 22.66 \\
\hline 2007 & 467 & 120 & $25.70 \%$ & $37.31 \%$ & 21.97 \\
\hline Total & 3,984 & 1,040 & $27.35 \%$ & $36.16 \%$ & \\
\hline \multicolumn{6}{|c|}{ Panel B: Type of Governance Proposals (Broad Classification)_ Summary Statistics } \\
\hline \multicolumn{2}{|l|}{ Proposal Type } & roposals & \multicolumn{2}{|c|}{ Mean Vote in Favor } & tage Approved \\
\hline \multicolumn{2}{|l|}{ Auditors } & 68 & \multicolumn{2}{|l|}{$22.70 \%$} & $4.40 \%$ \\
\hline \multicolumn{2}{|l|}{ Board } & 61 & \multicolumn{2}{|l|}{$22 \%$} & $8.80 \%$ \\
\hline \multicolumn{2}{|l|}{ Compensation } & 0 & \multicolumn{2}{|l|}{$23.00 \%$} & $4.20 \%$ \\
\hline \multicolumn{2}{|l|}{ G-Index } & 58 & \multicolumn{2}{|l|}{$51 \%$} & $53 \%$ \\
\hline \multicolumn{2}{|l|}{ Voting } & 1 & \multicolumn{2}{|l|}{$14 \%$} & $3.30 \%$ \\
\hline \multicolumn{2}{|l|}{ Other } & & \multicolumn{2}{|l|}{$33.90 \%$} & $21.00 \%$ \\
\hline
\end{tabular}

around the majority threshold. Among the 523 G-index proposals within five percentage points of the discontinuity, $219(42 \%)$ are proposals to repeal classified boards and $132(25 \%)$ are proposals to eliminate poison pills. Among the 387 Other (non-G-index) kinds of proposals around the discontinuity, 115 (or $30 \%)$ are proposals to elect directors through a majority vote and $68(18 \%)$ are proposals to expense stock options. Throughout the paper, we analyze two sets of proposals-G-index versus Other-both pooled and separately.

For the 948 firms that constitute our final sample, we obtain additional information from a number of sources: security prices from CRSP, financial information from Compustat, data on acquisitions from the SDC database, 


\section{Table II}

\section{Descriptive Statistics}

Our sample of 3,984 proposals corresponds to 2,377 firm-year observations. Abnormal Returns are computed from CRSP. G-index is the number of antitakeover provisions in place at the firm (Source Riskmetrics). All accounting variables are obtained from Compustat: Total Assets (AT), Market Value (mkvalt_f), Capital Expenses (CAPX). Tobin's $Q$ is defined as the market value of assets (AT+mkvalt_f-CEQ) divided by the book value of assets (AT), and balance sheet Deferred Taxes and Investment Tax Credit (TXDITC). Book-to-market is the ratio of book value of common equity (previous fiscal year) to market value of common equity (end of previous calendar year). Ownership by top five shareholders is the sum of institutional ownership for the top five shareholders in the last fiscal quarter before the meeting, and institutional shareholders that own at least 5\% is the number of shareholders that own at least $5 \%$ of the firm's stock (Source: Thomson 13F Database). Acquisitions Count is the number of acquisitions made in a year, Acquisitions Ratio is computed as the sum of all acquisition prices paid divided by the average market capitalization on the first and last day of the year (Source: SDC). All monetary values are in 1996 U.S. dollars. Note that the number of observations may change due to missing values for some of the variables.

\begin{tabular}{lccccc}
\hline & $N$ & Mean & Std. Dev. & 10th Per. & 90 th Per. \\
\hline Abnormal Return on meeting day & 2,377 & 0.001 & 0.023 & -0.020 & 0.023 \\
G-index & 2,050 & 9.5 & 2.5 & 6 & 13 \\
Total assets (\$millions) & 2,369 & $43,794.83$ & 124,155 & 718.83 & $85,775.73$ \\
Market value (\$millions) & 2,011 & 22,431 & 44,477 & 485 & 62,404 \\
EBITDA (\$millions) & 2,300 & $3,177.70$ & 6,320 & 52,29 & 8,223 \\
Capital expenses (\$millions) & 2,239 & 1,043 & 2,570 & 9.3 & 2,182 \\
R\&D/Assets & 2,369 & 0.018 & 0.045 & 0 & 0.065 \\
Ownership by top five shareholders & 2,301 & 0.245 & 0.095 & 0.136 & 0.367 \\
$\quad$ & & & & & \\
Institutional shareholders that own & 1,787 & 2.170 & 1.230 & 1 & 4 \\
$\quad$ at least 5\% & & & & & \\
Tobin Q & 1,805 & 1.588 & 0.69 & 1.01 & 2.67 \\
Book to market & 1,805 & 0.528 & 0.300 & 0.180 & 0.960 \\
Return on equity & 1,778 & 0.107 & 0.100 & -0.009 & 0.241 \\
Growth of capital expenses & 1,908 & 0.059 & 0.300 & -0.31 & 0.45 \\
Acquisitions ratio & 1,960 & 0.016 & 0.030 & 0 & 0.064 \\
Acquisitions count & 1,991 & 0.53 & 0.80 & 0 & 2.00 \\
\hline
\end{tabular}

and institutional ownership characteristics from Thomson Financial. ${ }^{7}$ Table II displays the characteristics of the firms in our sample.

\section{B. Identifying Shareholder Returns from Votes on Governance Proposals}

In this section, we present an analytical framework that shows how to recover the value of a governance provision by focusing on close votes in shareholdersponsored governance proposals. We show that a discontinuity analysis is a

\footnotetext{
${ }^{7}$ Most of these data sets are recorded at the end of the fiscal year. To determine what is the first observation after a vote, we require that the end of the fiscal year be at least 6 months after the meeting in which the vote is recorded. If it is less than 6 months after, then we use the following year available as the first year after the meeting.
} 


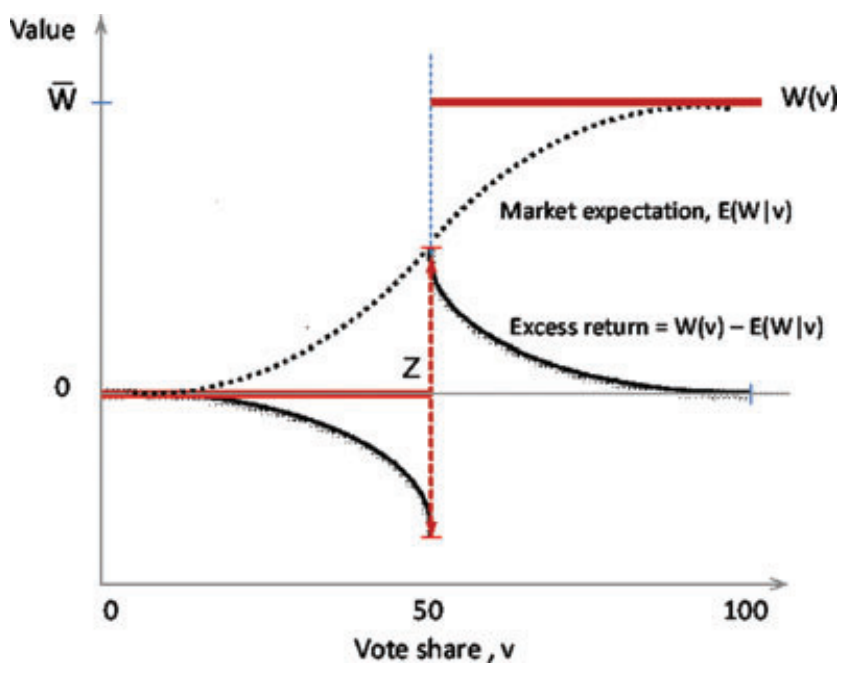

Figure 1. Market reaction to vote outcomes.

simple way to deal with the presence of prior expectations in an event study. Figure 1 provides an illustration. Denote $v$ as the vote share in favor of passing a proposal and $W(v)$ as the value to the firm of a particular vote outcome. For simplicity, we assume throughout this illustration that the outcome of the vote is always binding, that the majority threshold for a vote to be approved is $v \geqslant \frac{1}{2}$, and that the value of the proposal to the firm is fixed (i.e., independent of $v$ ), such that $W(v)=\bar{W}$ if $v \geqslant \frac{1}{2}$ and zero otherwise. Figure 1 represents $W(v)$ and shows the change in the underlying value of the firm after the vote. The objective of the empirical analysis is to estimate $\bar{W}$, the value of implementing a governance proposal, which is not directly observable. As the day of the vote approaches, investors use all the available information to form an expectation of the probability that the proposal will succeed, and this expectation is incorporated in stock prices. Therefore, the price reaction, that is, the abnormal return that we observe when the outcome of the vote is known is the difference between the actual value of the proposal to the firm $W(v)$ (which is either $\bar{W}$ or zero, depending on whether it passes) and its expected value before the vote $E(W \mid v)$ (the average price that the market had formed for a given observed vote outcome). We represent $E(W \mid v)$ by a dashed line in Figure 1 . The intuition behind $E(W \mid v)$ is that, for votes that have a vote share $v$ close to zero, the market had already assigned a low probability that they would pass. Therefore, $E(W \mid v)$ is close to zero. Similarly, for votes around $100 \%$, the market assigned a high probability of passing, and $E(W \mid v)$ is close to $\bar{W}$. In contrast, around the threshold, on average the market had assigned a $50 \%$ probability that the vote would pass, and $E(W \mid v)$ is close to $\frac{1}{2} \bar{W} .^{8}$

\footnotetext{
8 The Internet Appendix describes analytically how to derive $E(W \mid v)$ and the price reaction for any vote outcome, taking into account the full distribution of prior expectations.
} 
Since $E(W \mid v)$ is a continuous function of $v$ but $W(v)$ is discontinuous at the majority threshold, the abnormal return that one observes when the outcome of the vote is known is also discontinuous at the majority threshold. In fact, the difference in abnormal returns at the majority threshold $-Z$ in Figure 1-between a vote that barely fails and one that barely passes is exactly the value of the proposal. Under the set of assumptions outlined earlier, $Z=(\bar{W}-E(W \mid v))-(0-E(W \mid v))=\bar{W}$. Therefore, one can recover the value of the proposal from the difference in abnormal returns of close-call votes or, in other words, at the discontinuity. The only two crucial identification assumptions are that the distribution of firm characteristics and vote expectations is similar on both sides of the discontinuity and that the probability of implementing the proposal changes discretely when a proposal passes. Note that this analysis can be generalized to other discontinuity treatments that are not based on votes.

The earlier example made a number of additional assumptions that may not necessarily hold in reality but are not crucial for the identification. In practice, shareholder proposals are typically not binding. A proposal may pass but not be implemented; thus, $W(v)$ will be below the effective value of the proposal to the right of the threshold, and the market reaction to proposals that pass by a close margin will be less positive than if the vote were binding. Similarly, if management feels that a proposal that fails to pass by a few votes should still be implemented, $W(v)$ will be slightly positive to the left of the threshold and the market reaction will be less negative. Furthermore, $W(v)$ may incorporate the probability that the current vote will trigger another proposal in the future that in turn may or may not pass. As a result, $E(W \mid v)$ and abnormal returns are not necessarily symmetric around the threshold, as in our simple example in Figure 1 (the Internet Appendix illustrates this case). ${ }^{9}$ Still, provided that $E(W \mid v)$ is continuous and the probability of implementation discontinuous around the threshold, $Z$ can be used to measure the value of the proposal to the firm. In this case, the value estimated at the discontinuity, $Z$, is not equal to $\bar{W}$, as in the previous example. To recover the value of $\bar{W}$ from our estimate $Z$, we need to consider the fact that, around the discontinuity, the market is updating both the probability of implementation and the chances of proposing and passing future proposals.

Therefore, our identification strategy does not require that proposals be binding. As Lee and Lemieux (2010) discuss, the identification strategy is still valid as long as there is a discrete jump in the probability of implementation at the majority threshold (this is the "fuzzy" regression discontinuity setting). ${ }^{10}$ It

\footnotetext{
9 The Internet Appendix for this article is available online in the "Supplements and Datasets" section at http://www.afajof.org/supplements.asp.

${ }^{10}$ In Ertimur, Ferri, and Stubben (2010), the change in the probability of implementation at the majority threshold can be inferred to be around 20.7\%; in Section IV.A.3, we estimate a discrete change in the implementation probability of $30.1 \%$ within 2 years for the subset of proposals that affect the G-index. Ertimur, Ferri, and Stubben (2010) also show that the probability of implementation increases in the vote share: proposals with $50 \%$ to $60 \%$ of the votes in favor have a $23.9 \%$ probability of implementation, while proposals with $90 \%$ to $100 \%$ of the votes in favor have a $78.6 \%$ probability of implementation.
} 
is also important to emphasize that the estimate recovered using the discontinuity analysis is the average effect of the governance proposals with votes around the threshold. Below, we discuss which proposals fall around the majority threshold in the data.

We can define $p^{I}$ as the difference in the probability of implementation of a proposal that passes by a small margin relative to one that fails by a small margin. Similarly, we can define $p_{t+i}^{p}$ as the endogenous change in the probability of passing and subsequently implementing another proposal $i$ periods from now (as a result of the current proposal passing at the discontinuity). Assuming a discount rate of $\delta^{i}$, the market reaction at the threshold $Z$ can therefore be written as the sum of two elements: the value associated with the current proposal being implemented $\left(p^{I} \bar{W}_{f}\right)$ plus the discounted value of future proposals being passed and implemented as a result of the current proposal passing $\left(\sum_{i=1}^{\infty} \delta^{i} p_{t+i}^{p} \bar{W}_{f}\right)$. So, once we obtain estimates $p^{I}$ and $p_{t+i}^{p}$ from the data, the value of the proposal can be recovered as

$$
\bar{W}_{f}=\frac{Z}{p^{I}+\sum_{i=1}^{\infty} \delta^{i} p_{t+i}^{p}} .
$$

One important question that arises when trying to infer the value of a proposal from the abnormal returns at the discontinuity is whether we should expect any effect of votes that barely pass or fail. Shareholder votes should reflect a value-maximizing decision. If all shareholders were trying to maximize shareholder value, and in the absence of transaction costs, then they should all vote in the same way, in favor of or against a proposal. If shareholders are identical but have different information on the value of a proposal, then some votes would fall around the discontinuity, and those would correspond to proposals whose value to the firm is neutral or uncertain. However, when the objective of some shareholders is not to maximize shareholder value (say, in the presence of other private benefits), then the outcome of the vote will depend on the distribution of their preferences. In this sense, it is well-documented that different types of shareholders vote differently because they are heterogeneous in their objectives and may have other stakes in the firm. For example, it has been shown that banks and insurance companies tend to side with management by voting against the proposals, while mutual funds, unions, advisors, and pension funds tend to support the proposals (Brickley, Lease, and Smith (1988), Agrawal (2008)). The fact that we find positive abnormal returns at the discontinuity suggests that there are decisions that maximize shareholder value but are hard to implement.

\section{Abnormal Returns as a Function of Votes: Graphical Evidence}

Figure 2 shows the impact of passing a proposal on shareholder abnormal returns on the day of the meeting. We calculate the daily abnormal returns from CRSP, using the three Fama-French factors and the momentum factor 


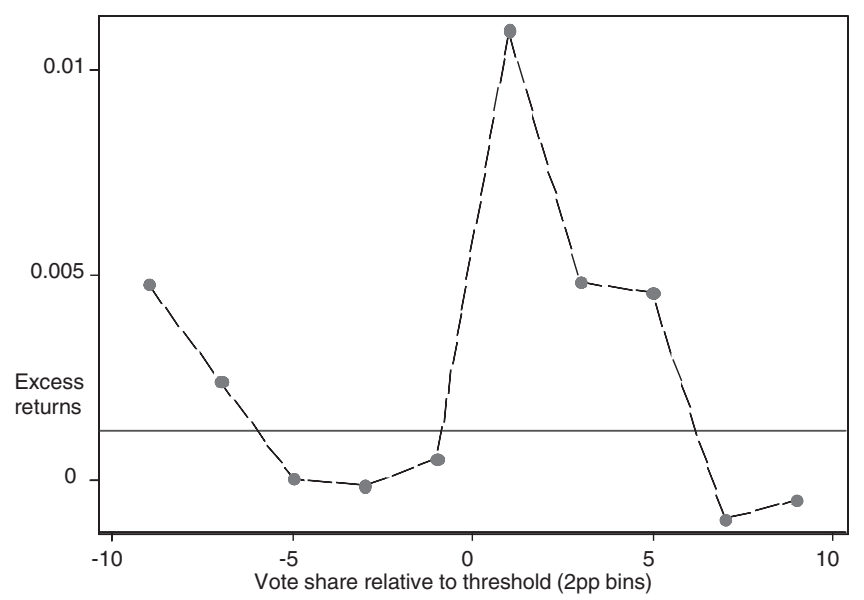

Figure 2. Excess returns by vote share on the day of the vote. The figure shows average excess returns by the vote share in favor of the proposal. Proposals are grouped into two percentagepoint bins: proposals that passed by between $0.001 \%$ and $2 \%$ are assigned to the 1 bin, and those that failed by similar margins are assigned to the -1 bin. Excess returns are computed using the Fama-French and momentum factors from Carhart (1997).

from Carhart (1997). ${ }^{11}$ Figure 2 is the empirical counterpart of Figure 1. In practice, since vote outcomes are not binding and may trigger future proposals, this can make the effects nonsymmetric around zero (as shown in the Internet Appendix). The graph plots the average daily abnormal return for the day of the meeting $(t=0)$ when the information of the vote is revealed. The $x$-axis reflects the margin of victory (the vote share minus the threshold for that vote). On the day of the vote, proposals that pass by a small margin have positive abnormal returns, and comparing those to proposals that fail by a small margin gives us the effect of passing a proposal on abnormal returns. Notice that proposals that pass by more than a 5\% margin display zero abnormal returns, which is consistent with the fact that the market can forecast with some accuracy the probability of passing a proposal and this is incorporated in prices. Most firms disclose vote outcomes on the same day of the annual meeting through a variety of channels (newswires and real-time broadcast). Independently, institutional investors such as CALPERS provide news posts on voting results. The media covering these corporate events releases additional information.

Figure 2 is an intuitive representation of the main result of the paper: closecall governance proposals that pass lead to positive abnormal returns on the day of the vote, while those that do not pass lead to negative or negligible ones. Before showing regression results (in Section IV), over the next two sections we describe the methodology that uses all the data efficiently and we test the validity and generality of our approach.

\footnotetext{
11 The estimation period starts 2 months prior to the event date; the length of the estimation period is 200 trading days, and we require at least 15 days with returns to make it into the sample.
} 


\section{Methodology and Identification Strategy}

This section describes how to adapt the regression discontinuity methodology to an event study in order to estimate the effect of shareholder governance proposals on shareholder returns.

\section{A. Regression Discontinuity in Shareholder Votes}

Suppose that shareholders of firm $f$ vote on a shareholder proposal at time $t$, the meeting date, and that this proposal gets a total vote share (percentage of votes in favor) $v_{f t}$. If $v_{f t}$ is larger than the majority threshold $v^{*}$, then this proposal passes and we code the indicator for pass as $D_{f t}=1\left(v_{f t} \geqslant v^{*}\right)$.

We are interested in the effect that passing a certain proposal has on an outcome variable $y_{f t}$. We can write

$$
y_{f t}=\kappa+D_{f t} \theta+u_{f t},
$$

where the coefficient $\theta$ that we are interested in is the effect of passing a proposal in a shareholder meeting on the outcome variable $y_{f t}$-for example, abnormal returns-and $u_{f t}$ represents all other determinants of the outcome $\left(E\left(u_{f t}\right)=0\right)$. The problem with estimating a regression such as (2) directly is that the passage of a proposal is a highly endogenous outcome, and $D_{f t}$ is unlikely to be independent of the error term $\left(E\left(D_{f t}, u_{f t}\right) \neq 0\right)$, in which case the estimate of $\theta$ will be biased.

To get a consistent estimate, we would ideally want "passing" a proposal to be a randomly assigned variable. The regression discontinuity framework that exploits the vote shares helps us to approximate this ideal setup because, in an arbitrarily small interval around the discontinuity (the threshold $v^{*}$ ), whether the proposal passed or failed is random (e.g., whether a proposal passes by $50.1 \%$ or fails by $49.9 \%$ is random). Lee (2008) formally shows that, as long as there is a random component to the vote, the assignment into "treatment" (pass and $D_{f t}=1$ ) and "control" (fails and $D_{f t}=0$ ) groups is random around the threshold. ${ }^{12}$ This implies that our estimate of $\theta$ using the regression discontinuity design is not affected by omitted variables-such as firm announcements-even if they are correlated with the vote, as long as their effect is continuous around the threshold. Therefore, by comparing the outcome $y_{f t}$ of votes that barely passed to the outcome of votes that barely failed, we get a consistent estimate of the value of a new governance rule.

To use all our data and improve efficiency, we follow the standard approach (see Lee and Lemieux (2010)) and assume that we can approximate the continuous underlying relationship between $y_{f t}$ and $v_{f t}$, with a polynomial in the vote share. This polynomial flexibly captures the underlying relationship between any variable that is continuously affected by the vote share and the outcome

\footnotetext{
12 This random component contains all kinds of events that make the voting outcome not fully predictable (such as shareholder turnout, undecided voters, and last minute information). It does not need to be large for our purposes, given that we perform a local analysis.
} 
variable. Only the discontinuous effects at the threshold are captured by $\widehat{\theta}$. Allowing for a different polynomial for observations on the right-hand side of the threshold $P_{r}\left(v_{f t}, \gamma^{r}\right)$ and on the left-hand side of the threshold $P_{l}\left(v_{f t}, \gamma^{l}\right)$ gives

$$
y_{f t}=D_{f t} \theta+P_{r}\left(v_{f t}, \gamma^{r}\right)+P_{l}\left(v_{f t}, \gamma^{l}\right)+u_{f t} .
$$

The estimate, $\widehat{\theta}$, is precisely the estimate of $Z$ from Section I.A (Figures 1 and 2). Therefore, when $y_{f t}$ are abnormal returns, the regression discontinuity model yields a consistent estimate of $Z$.

\section{B. Panel Data, Multiple Votes, and Multiple Shareholder Meetings}

Two issues emerge when trying to implement the standard regression discontinuity model of expression (3) to analyze the effect of governance rules in our data, and in any event study. The first is that the event (the election) at time $t$ will have an impact on outcomes at times $t+1, t+2$, etc. The second is that, for each firm and meeting date, shareholders may have to vote on more than one governance issue. Therefore, we need to find a way to aggregate all votes by firm and meeting date. This is particularly relevant for event studies given that, on any particular date, there may be multiple treatments.

\section{B.1. Dynamics in the Impact of the Votes}

We follow the empirical model in Cellini, Ferreira, and Rothstein (2010) to characterize the dynamic version of the regression discontinuity for a firm $f$ that has a vote at time $t$, and we define the outcome $\tau$ periods later $y_{f, t+\tau}$ as

$$
y_{f, t+\tau}=D_{f t} \theta^{\tau}+P_{r}\left(v_{f t}, \gamma_{\tau}^{r}\right)+P_{l}\left(v_{f t}, \gamma_{\tau}^{l}\right)+u_{f t, t+\tau} .
$$

The term $\theta^{\tau}$ estimates the causal effect of passing a vote at time $t$ on outcomes at $t+\tau$. As Cellini, Ferreira, and Rothstein (2010) note, estimating expression (4) separately for each period $t+\tau$ is inefficient because there is an important component that is fixed within firms over time but that varies across firms. We follow their strategy, pooling data for multiple $\tau$ (including $\tau<0$ ) and including controls to absorb firm-level heterogeneity. For each election in our data $(f, t)$, we use observations for firm $f$ in periods $t-2$ to $t+T$ ( $T$ is up to 7 days after the election for abnormal returns and 4 years after the election for other outcomes). We then estimate

$$
y_{f, t+\tau}=D_{f t} \theta^{\tau}+P_{r}\left(v_{f t}, \gamma_{\tau}^{r}\right)+P_{l}\left(v_{f t}, \gamma_{\tau}^{l}\right)+\alpha_{\tau}+\eta_{c}+\lambda_{f t}+e_{f t \tau} .
$$


This follows expression (7) in Cellini, Ferreira, and Rothstein (2010) (see more details for the sample construction in that paper). ${ }^{13}$ The parameters $\alpha_{\tau}, \eta_{c}$, and $\lambda_{f t}$ are fixed effects for time periods relative to the meeting date, calendar years, and focal elections, respectively. The parameters, $\theta^{\tau}, \gamma_{\tau}^{r}$, and $\gamma_{\tau}^{l}$ are allowed to vary for $\tau \geqslant 0$, and constrained to zero for $\tau<0$, and standard errors are clustered by firm $f$. Here, $\theta^{\tau}$ is the effect of passing a proposal at time $t$ on outcomes $\tau$ periods later, and we obtain separate estimates for the contemporaneous effect $(\tau=0)$, one period later $(\tau=1)$, etc. Notice that this dynamic model allows us to introduce focal meeting fixed effects $\lambda_{f t}$, which will absorb any characteristic of the meeting that affects outcomes in periods $t+\tau$ (e.g., characteristics of the firm that are constant during the event window). Information is released mainly on the day of the vote, but in any case this dynamic structure would capture any effect in subsequent days.

\section{B.2. Aggregating Votes}

Next, since there is only one outcome (e.g., one abnormal return) per meeting, we need to find a way to aggregate all votes for a given firm and meeting date. To illustrate how we do this, we first ignore dynamics and use the simple (nondynamic) expression (3). Imagine that the firm could vote on two issues, $\mathrm{A}$ and $\mathrm{B}$, on any given date. Then we would extend expression (3) to allow for two different kinds of votes to affect $y_{f t}$

$$
\begin{aligned}
y_{f t}= & D_{f t}^{A} \theta^{A}+D_{f t}^{B} \theta^{B}+P_{r}^{A}\left(v_{f t}^{A}, \gamma^{A, r}\right)+P_{r}^{B}\left(v_{f t}^{B}, \gamma^{B, r}\right)+P_{l}^{A}\left(v_{f t}^{A}, \gamma^{A, l}\right) \\
& +P_{l}^{B}\left(v_{f t}^{B}, \gamma^{B, l}\right)+u_{f t},
\end{aligned}
$$

where $\theta^{A}$ and $\theta^{B}$ would be the effect of proposals of type A and B on the outcome of interest. The problem is that there are not just two types of governance proposals, but 72 (see the Appendix). Given that we identify effects only around the discontinuity, the number of observations limits the degree to which we can separate out the effects. However, under the assumption that for all $K, \theta^{K}=\theta$, $P_{r}^{K}=P_{r}$, and $P_{l}^{K}=P_{l}$, we can rewrite expression (3) as

$$
y_{f}=\theta \sum_{K=1}^{N} D_{f t}^{K}+\left[P_{r}\left(\sum_{K=1}^{N} v_{f t}^{K}, \gamma^{K, r}\right)+P_{l}\left(\sum_{K=1}^{N} v_{f t}^{K}, \gamma^{K, l}\right)\right]+u_{f t} .
$$

The coefficient $\theta$ is the average causal effect of a proposal. To allow for more flexibility than this arguably restrictive but practical assumption allows, we let $\theta$ vary by two relevant groups of proposals (antitakeover provisions vs. other proposals). We also let the effect of $\theta$ be nonlinear in the number of proposals

\footnotetext{
13 This yields the Intent To Treat (ITT) estimator in Cellini, Ferreira, and Rothstein (2010), who demonstrate how to derive Treatment On the Treated (TOT) estimates in the dynamic regression discontinuity setting. For our daily shareholder return regressions, ITT and TOT are identical since there is only one election per year and hence no intervening elections between $t$ and $t+7$ where $t$ is measured in days.
} 

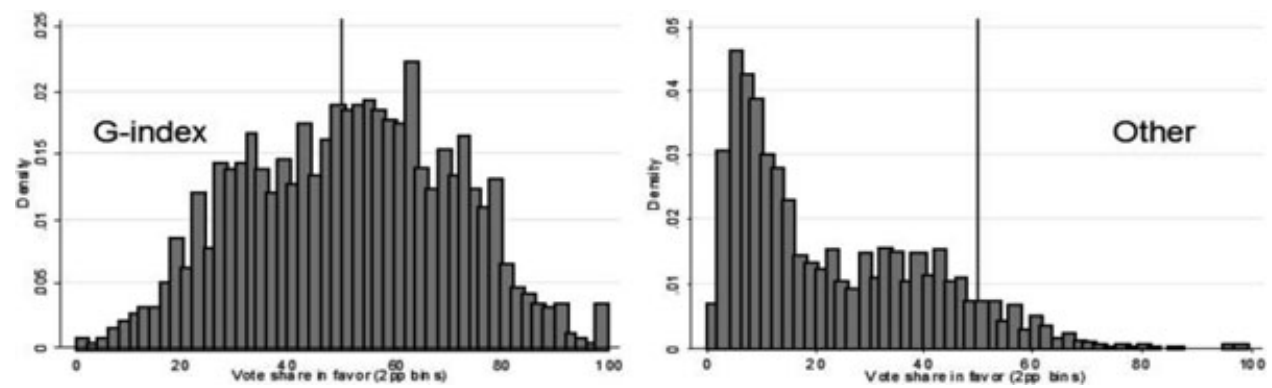

Figure 3. Distribution of vote shares for other shareholder governance proposals. The left panel includes G-index proposals $(N=1,558)$ and the right panel includes all "Other" shareholder proposals $(N=2,426)$ from 1997 to 2007 .

passed. As we will see, the effect is approximately linear. When we restrict our analysis to meetings in which only one governance proposal is voted on (in which case we do not need to aggregate across proposals), we obtain results similar to those using multiple votes in a day. Thus, expression (6) appears to be a good way to summarize the data.

When we put together expressions (5) and (6), which recognize the dynamic structure of the data and the need to aggregate over $N$ proposals, we obtain our estimating expression

$$
\begin{aligned}
y_{f, t+\tau}= & \theta^{\tau} \sum_{K=1}^{N} D_{f t}+\left[P_{r}\left(\sum_{K=1}^{N} v_{f t}^{K}, \gamma_{\tau}^{K, r}\right)+P_{l}\left(\sum_{K=1}^{N} v_{f t}^{K}, \gamma_{\tau}^{K, l}\right)\right]+\alpha_{\tau}+\eta_{c} \\
& +\lambda_{f t}+e_{f t \tau} .
\end{aligned}
$$

Throughout the paper, we use a polynomial of order four on either side of the threshold. The Internet Appendix shows that our results are similar when using higher order polynomials, indicating that we are capturing a truly discontinuous effect.

\section{Election Votes as a Quasi-Experiment: Vote Distribution and Preexisting Differences}

The basic assumption of the regression discontinuity design is that, around the threshold, passing a proposal is as good as random assignment. Here, we provide a standard test of this assumption that evaluates whether the distribution of votes is continuous around the majority threshold. Figure 3 shows the distribution of the vote share (the percentage of votes in favor) for proposals to remove antitakeover provisions (those included in the G-index), and Other proposals to increase shareholder control (including compensation, board-related, and auditor-related proposals). If there were sharp changes in that distribution around the threshold, this would indicate that the probability of falling on either side of the threshold is discontinuous and that the main 
identification assumption is not likely to hold (McCrary (2008)). We see that the distribution is smooth around the threshold. ${ }^{14}$

Figure 3 also shows that antitakeover proposals are more likely to fall around the discontinuity. Since our estimates are identified only from observations around the discontinuity, this implies that most of the effect we estimate comes from the passage of antitakeover provisions. It also limits the extent to which we can try to identify the effects of different subgroups since we do not have enough observations around the threshold.

A second standard test of the regression discontinuity design evaluates whether, prior to the day of the vote, there were systematic differences in the characteristics of firms that fall on either side of the threshold. The main assumption of the design is that there are no systematic differences in characteristics from firms that marginally pass, relative to those that marginally reject, a proposal. The first column in each panel of Table III evaluates whether, before the meeting, firms that pass a proposal have different characteristics from firms that reject a proposal. The regressions in column 1 do not control for a polynomial in the vote share, and hence they estimate the average predifference in characteristics across all firms. The regressions in column 2 include the polynomials of order four on either side of the threshold, and thus they estimate the effect at the discontinuity. We see that there is no significant difference in abnormal returns on the day before the meeting, in 1-week cumulative returns, in 1-month cumulative returns (panel A), or in Tobin's $Q$, capital expenditures, return on equity, or R\&D over assets in the year before the meeting (panel B). There is no difference in the growth rates of those variables, on average (column 3), and, most importantly for our identification, around the discontinuity (column 4), which indicates the absence of preexisting differences. Panel $\mathrm{C}$ examines two acquisitions variables (number and value of acquisitions), and neither has significant differences around the threshold.

Next, we examine differences in ownership concentration for institutional owners (panel D). As mentioned, the presence of institutional owners is likely to be a determinant of the outcome of the vote. In column 1 , panel $\mathrm{D}$, we find that a proposal is indeed more likely to pass in firms with a high reported concentration of institutional owners (measured as the sum of institutional ownership for the top five shareholders in the last fiscal quarter before the meeting) or with more institutional owners that report owning at least $5 \%$ of shares outstanding. ${ }^{15}$ This confirms the fact that one cannot directly compare firms with or without governance provisions in place since these are different

\footnotetext{
${ }^{14}$ We perform the formal density test for smoothness of the vote share suggested in McCrary (2008) and cannot reject smoothness around the majority threshold. See the Internet Appendix. Listokin (2008) also reports a smooth distribution of shareholder-sponsored proposals around the majority threshold as evidence of lack of strategic behavior. However, he shows that management proposals (which are excluded from our analysis) display a very sharp discontinuity in the density of votes at the majority threshold. Essentially, these rarely fail, as management strategically withdraws those proposals that are likely to fail.

15 These two variables are computed using SEC Form 13 F quarterly filings, provided by Thomson Financial.
} 


\section{Table III}

\section{Pre-existing Differences in Firm Characteristics as a Function of the Vote Outcome}

The table tests whether passing a vote on the meeting date is systematically related to firm characteristics prior to the meeting. Note that in panel A $t$ refers to days, in panels B to E, $t$ refers to years. Each row corresponds to a different dependent variable and each entry comes from a separate regression. Each entry in the table reports the coefficient on whether a proposal passed. Columns 1 and 2 ( 3 and 4) report the estimated effect of passing a vote on outcome variable levels (changes) the year before the annual meeting, $t-1$ (between $t-2$ and $t-1$ ). Columns 1 and 3 present estimates without controlling for a polynomial in the vote share and, therefore, estimate the average effect of passing relative to not passing. Columns 2 and 4 include the polynomial in the vote share of order four on each side of the threshold such that it effectively estimates the effect at the discontinuity. All columns control for year fixed effects and standard errors (in parentheses) are clustered at the firm level. Significance at the $10 \%, 5 \%$, and $1 \%$ levels is indicated by ${ }^{* *}$, and ***, respectively.

\begin{tabular}{|c|c|c|c|c|}
\hline & \multicolumn{2}{|c|}{ Before meeting $(t-1)$} & \multicolumn{2}{|c|}{$\begin{array}{l}\text { Change from }(t-2) \text { to } \\
\qquad(t-1)\end{array}$} \\
\hline & (1) & (2) & (3) & (4) \\
\hline \multicolumn{5}{|c|}{ Panel A } \\
\hline $\begin{array}{l}\text { Abnormal return } 1 \text { day before meeting, } \\
\text { Car }(-1,-1)\end{array}$ & $\begin{array}{l}-0.00002 \\
(0.001)\end{array}$ & $\begin{array}{r}-0.004 \\
(0.003)\end{array}$ & n.a. & n.a. \\
\hline Cumul. returns 1 week before meeting & $\begin{array}{c}-0.0002 \\
(0.002)\end{array}$ & $\begin{array}{c}0.0068 \\
(0.0079)\end{array}$ & n.a. & n.a. \\
\hline Cumul. returns 1 month before meeting & $\begin{array}{c}-0.0024 \\
(0.0034)\end{array}$ & $\begin{array}{c}0.0006 \\
(0.0156)\end{array}$ & n.a. & n.a. \\
\hline \multicolumn{5}{|c|}{ Panel B } \\
\hline Tobin $Q$ & $\begin{array}{r}-0.010 \\
(0.068)\end{array}$ & $\begin{array}{c}0.254 \\
(0.191)\end{array}$ & $\begin{array}{c}0.014 \\
(0.029)\end{array}$ & $\begin{array}{c}0.041 \\
(0.101)\end{array}$ \\
\hline Capital expenses/Assets & $\begin{array}{r}-0.001 \\
(0.003)\end{array}$ & $\begin{array}{l}-3.88 \times 10^{-6} \\
(0.006)\end{array}$ & $\begin{array}{c}-0.002 \\
(0.001)\end{array}$ & $\begin{array}{c}0.003 \\
(0.003)\end{array}$ \\
\hline Return on equity & $\begin{array}{c}1.65 \\
(1.63)\end{array}$ & $\begin{array}{c}-0.83 \\
(1.2)\end{array}$ & $\begin{array}{c}1.63 \\
(1.68)\end{array}$ & $\begin{array}{c}-0.69 \\
(1.21)\end{array}$ \\
\hline R\&D/Assets & $\begin{array}{c}0.003 \\
(0.002)\end{array}$ & $\begin{array}{c}-0.002 \\
(0.006)\end{array}$ & $\begin{array}{l}-0.00002 \\
(0.001)\end{array}$ & $\begin{array}{c}0.002 \\
(0.001)\end{array}$ \\
\hline \multicolumn{5}{|c|}{ Panel C } \\
\hline Acquisitions ratio & $\begin{array}{c}0.007 \\
(0.010)\end{array}$ & $\begin{array}{l}-0.04 \\
(0.041)\end{array}$ & $\begin{array}{c}-0.023 \\
(0.010)\end{array}$ & $\begin{array}{c}-0.021 \\
(0.073)\end{array}$ \\
\hline Acquisitions count & $\begin{array}{r}-0.124^{*} \\
(0.070)\end{array}$ & $\begin{array}{c}0.193 \\
(0.21)\end{array}$ & $\begin{array}{r}-0.067 \\
(0.064)\end{array}$ & $\begin{array}{c}0.305 \\
(0.267)\end{array}$ \\
\hline \multicolumn{5}{|c|}{ Panel D } \\
\hline Percentage ownership by top five shareholders & $\begin{array}{l}3.121^{* * *} \\
(0.616)\end{array}$ & $\begin{array}{l}-0.856 \\
(1.255)\end{array}$ & $\begin{array}{c}0.092 \\
(0.217)\end{array}$ & $\begin{array}{c}0.849 \\
(0.83)\end{array}$ \\
\hline Institutional shareholders that own at least $5 \%$ & $\begin{array}{l}0.319 * * * \\
(0.072)\end{array}$ & $\begin{array}{l}-0.24 \\
(0.199)\end{array}$ & $\begin{array}{c}0.018 \\
(0.049)\end{array}$ & $\begin{array}{l}0.29 \\
(0.204)\end{array}$ \\
\hline \multicolumn{5}{|c|}{ Panel E } \\
\hline G-index & $\begin{array}{l}1.242^{* * *} \\
(0.180)\end{array}$ & $\begin{array}{c}-0.514 \\
(0.391)\end{array}$ & $\begin{array}{c}-0.078 \\
(0.051)\end{array}$ & $\begin{array}{c}-0.101 \\
(0.173)\end{array}$ \\
\hline Polynomial in the vote share & no & yes & no & yes \\
\hline
\end{tabular}


kinds of firms. However, once we include the polynomial in the vote share in column 2 of panel D, we see that there is no significant difference around the threshold, which lends support to our identifying assumption.

Similarly, one expects that firms with different levels of shareholder rights, as measured by the G-index, have different propensities to pass shareholders' governance proposals. Column 1 of panel $\mathrm{E}$ shows that firms with a higher G-index (more antitakeover provisions in place) are more likely to pass the shareholder proposals. However, firms around the vicinity of the discontinuity do not differ along this dimension, which further supports the paper's basic identifying assumption. Finally, we also examine a number of additional meeting characteristics, such as the number of proposals, the number of withdrawn proposals prior to the annual meeting, and the identity of the proponent, and we find no evidence of preexisting differences at the discontinuity (see the Internet Appendix). Overall, we find no evidence of selection into either side of the discontinuity based on observable variables. This lends support to our identification strategy, which is specifically designed to be unaffected by any variable (observable or unobservable) that is continuous in the vote share. However, there is still scope for effects that change discontinuously at the majority threshold as a result of the vote. For example, if management changes its announcements at the meeting upon seeing that a proposal passed by a small margin, this interim reaction will be incorporated in prices. Our estimate can be interpreted as capturing a governance effect only to the extent that such changes can be interpreted as indicative of governance improvements or indirect effects of passing a proposal.

\section{Results}

\section{A. Market Reaction to Exogenous Changes in Governance}

\section{A.1. The Effect of Governance Proposals on Abnormal Returns}

Table IV reports estimates of the difference in abnormal returns between proposals that pass and proposals that do not pass for increasingly small intervals around the election threshold on the day of the vote (standard errors are clustered by firm). Column 1 estimates this difference on the whole sample, and shows that there is no difference, on average, between those proposals that pass and those that fail (a highly insignificant estimate of 0.0009). The lack of significant results is driven by votes that pass or are rejected by a large margin (e.g., by more than a $10 \%$ margin as reported in column 2 ). This possibly reflects the fact that these nonclose votes are highly predictable and the market incorporates the expectation in the prices prior to the vote. Column 3 restricts the sample to proposals that fall within 10 percentage points of the threshold, and here we begin to see a higher estimate $(0.002$ - that is, $0.2 \%$ daily abnormal return) and a smaller standard error. For votes within five percentage points of the threshold, the abnormal return is $0.76 \%$ higher for those that passed (significant at the 1\% level), and as we narrow the window even further to two percentage points (column 5) and one percentage point (column 6) 


\section{Table IV}

\section{Abnormal Returns around the Majority Threshold}

This table presents regressions of the abnormal returns on the day of the meeting $t=0$ on whether the proposal passed. Abnormal returns are computed using the Fama-French and momentum factors from Carhart (1997). Column 1 estimates are based on the whole sample. Column 2 restricts the sample to nonclose votes, that is, votes beyond 10 points of the threshold. Column 3 restricts the sample to observations with a vote share within 10 points of the threshold, column 4 to five points, and so forth. Column 7 introduces a polynomial in the vote share of order four, one on each side of the threshold, and uses the full sample. All columns control for year fixed effects; standard errors are clustered by firm. Significance at the 10\%, 5\%, and 1\% levels is indicated by *, ${ }^{* *}$, and ***, respectively.

\begin{tabular}{lccccccc}
\hline \multicolumn{7}{c}{ All Shareholders Proposals } \\
\hline & $(1)$ & $(2)$ & $(3)$ & $(4)$ & $(5)$ & $(6)$ & $(7)$ \\
& All Votes & Nonclose & $-10 ;+10$ & $-5 ;+5$ & $-2 ;+2$ & $-1 ;+1$ & Full Model \\
\hline \multirow{2}{*}{ Pass } & 0.000922 & -0.000071 & 0.00230 & $0.00761^{* * *}$ & $0.0105^{* *}$ & $0.0139^{*}$ & $0.0131^{* * *}$ \\
& $(0.000924)$ & $(0.0012)$ & $(0.00163)$ & $(0.00256)$ & $(0.00502)$ & $(0.00756)$ & $(0.00494)$ \\
Observations & 3904 & 2990 & 909 & 450 & 183 & 91 & 3904 \\
$R^{2}$ & 0.000 & 0.000 & 0.002 & 0.024 & 0.032 & 0.039 & 0.014 \\
\hline
\end{tabular}

the abnormal return of passing increases to $1.05 \%$ and $1.39 \%$, respectively. These figures are still significant, even though the number of observations falls as we narrow the window. ${ }^{16}$

Finally, column 7 makes use of all the data in the sample (as described in Section II.A) and introduces two polynomials of order four in the vote share, one on each side of the threshold (as in expression (3)). Using this model, we estimate that the effect of passing a proposal is $1.3 \%$, which is very close to the results of the unrestricted models of the earlier columns. ${ }^{17}$

Figure 4 shows the day-by-day difference in abnormal returns between firms in which a proposal passes or fails within five percentage points on either side of the majority threshold. We observe a clear peak in the difference in returns between firms that pass and firms that do not pass a proposal on the day of the vote, $t=0$ (this is the same as the coefficient in column 4 of Table IV). For other days around the annual meeting, there are no clear spikes or discernible pattern. This shows that the market incorporates the outcome of the vote on the day of the vote itself-when the outcome is known-and not before.

Table IV is a simple and transparent representation of our data, but it does not take into account the possibilities that several proposals can be voted on in 1 day, that the effect of the vote can potentially persist over more than 1 day, or that the returns are likely to be correlated over time, given that they respond to the same events. In order to incorporate these characteristics of the data, we use the full model described in expression ( 7). The results are reported in

\footnotetext{
${ }^{16}$ In the Internet Appendix, we find a similar pattern on both types of proposals, that is antitakeover provisions and all other proposals. Within one percentage point of the interval, passing an antitakeover provision yields a $2.2 \%$ abnormal return on the day of the vote.

${ }^{17} \mathrm{We}$ also test the robustness of our estimates to narrowing the vote-share window and simultaneously including a polynomial in the vote share and obtain similar results.
} 


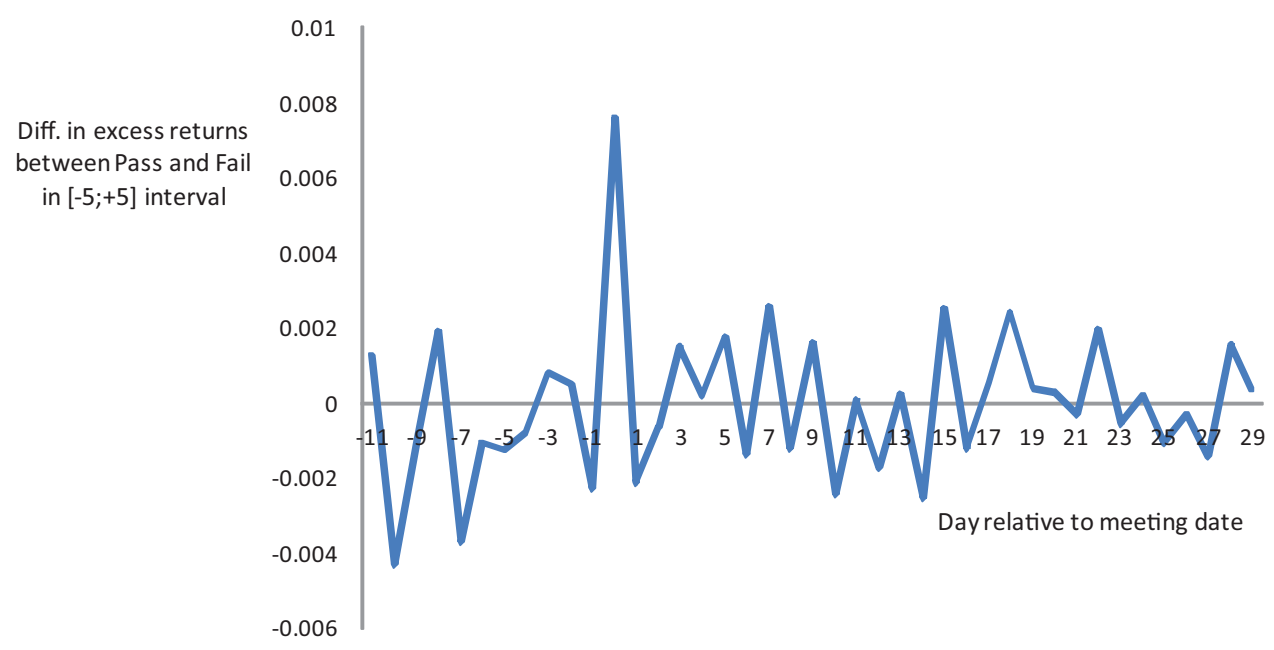

Figure 4. Day-by-day difference in excess returns, vote share in $[-\mathbf{5} ;+\mathbf{5}]$ interval. The $y$ axis measures the difference in daily excess returns between proposals that pass by a close margin [up to $+5 \%$ ] and proposals that are rejected by a close margin [up to $-5 \%$ ]. The $x$-axis shows the different days before and after the vote (date 0 is the day when the vote is passed).

Table V. Column 1 displays the effect of passing a proposal on the meeting date $(t)$, the day after $(t+1)$, and over the $t+2$ to $t+7$ period. We find that most of the effect (1.3\% abnormal return) is on the day of the vote, when the surprise around the threshold occurs. The following 6 days yield an additional return of $1.2 \%$, suggesting that there is no reversal of the effect. While this $1.2 \%$ is not statistically significant, the total cumulative effect after 1 week $(2.4 \%)$ is significant at the $10 \%$ level. Given the difference in precision between the two estimates, throughout the paper we favor the 1.3\% 1-day return as our more conservative but more precisely estimated coefficient of the market response to passing a proposal. Column 2 shows similar results using a different model to compute the daily abnormal returns (a standard one-factor market model instead of the three-factor Fama-French with momentum that we use in the rest of the analysis).

Overall, we find that, most of the effect on prices occurs on the day of the vote. In column 3, we further explore what happens on that day by allowing for a more flexible specification of the effect of the number of votes on daily returns (recall that the model in expression (7) sums over the votes of the day to aggregate over all the different outcomes). Here, we allow for different dummy variables for the number of proposals that passed, with a maximum of six proposals passing in a given meeting day. We find that the effect is monotonically increasing and approximately linear in the number of proposals. Therefore, the linearity assumption in the model in Section II.B.2 seems appropriate (the effect of passing one proposal is $1.3 \%$, similar to our baseline estimate; passing two proposals yields a $2.2 \%$ abnormal return; three and four proposals yield 


\section{Table V}

\section{Abnormal Returns of Passing Governance Proposals}

This table presents the effect of passing a proposal on abnormal returns on the meeting date $(t)$ and on the day after $(t+1)$ and the cumulative effect from $t+2$ to $t+7$. The dependent variable in columns 1,3 , and 4 is abnormal returns computed using the Fama-French and momentum factors (FFM) from Carhart (1997); in columns 2 and 5 it is abnormal returns computed using the market model (MM). In column 6, it is a dummy variable for whether abnormal returns are positive or negative. Column 3 allows for six different dummy variables to capture the number of proposals (one to six) that passed at the meeting. Columns 4,5, and 6 allow for a separate effect of antitakeover proposals (labeled as G-index proposals) and "Other" governance proposals. The specification in all columns is given by equation (7). All columns control for year fixed effects, firm-meeting fixed effects, and distance-to-the-election effects; standard errors in parentheses are clustered by firm. Significance at the $10 \%, 5 \%$, and $1 \%$ levels is indicated by *,**, and ${ }^{* * *}$, respectively.

\begin{tabular}{|c|c|c|c|c|c|c|c|}
\hline & \multicolumn{3}{|c|}{ Abnormal Returns } & \multicolumn{4}{|c|}{ Abnormal Returns G-index versus Other } \\
\hline & $\begin{array}{l}\text { FFM } \\
(1)\end{array}$ & $\begin{array}{c}\mathrm{MM} \\
(2)\end{array}$ & $\begin{array}{l}\text { FFM } \\
(3)\end{array}$ & & $\begin{array}{c}\text { FFM } \\
(4) \\
\text { G-index }\end{array}$ & $\begin{array}{c}\text { MM } \\
(5) \\
\text { G-index }\end{array}$ & $\begin{array}{c}\text { Positive Ret } \\
\text { (6) } \\
\text { G-index }\end{array}$ \\
\hline Day of vote, $t$ & $\begin{array}{l}0.013^{* *} \\
(0.005)\end{array}$ & $\begin{array}{l}0.014^{* * *} \\
(0.005)\end{array}$ & & Day of vote, $t$ & $\begin{array}{l}0.014^{* *} \\
(0.007)\end{array}$ & $\begin{array}{c}0.013^{*} \\
(0.007)\end{array}$ & $\begin{array}{l}0.156^{* *} \\
(0.070)\end{array}$ \\
\hline One day later, $t+1$ & $\begin{array}{c}0.002 \\
(0.004)\end{array}$ & $\begin{array}{c}0.004 \\
(0.004)\end{array}$ & $\begin{array}{c}0.002 \\
(0.004)\end{array}$ & One day later, $t+1$ & $\begin{array}{c}-0.001 \\
(0.006)\end{array}$ & $\begin{array}{c}0.000 \\
(0.006)\end{array}$ & $\begin{array}{c}0.074 \\
(0.073)\end{array}$ \\
\hline Days $t+2$ to $t+7$ & $\begin{array}{c}0.010 \\
(0.006)\end{array}$ & $\begin{array}{c}0.007 \\
(0.007)\end{array}$ & $\begin{array}{c}0.010 \\
(0.006)\end{array}$ & Days $t+2$ to $t+7$ & $\begin{array}{c}0.011 \\
(0.009)\end{array}$ & $\begin{array}{c}0.010 \\
(0.009)\end{array}$ & $\begin{array}{c}0.064 \\
(0.073)\end{array}$ \\
\hline Day of vote, $t$ & & & & & Other & Other & Other \\
\hline One vote passed & & & $\begin{array}{l}0.013^{* *} \\
(0.005)\end{array}$ & Day of vote, $t$ & $\begin{array}{c}0.009 \\
(0.006)\end{array}$ & $\begin{array}{l}0.012^{* *} \\
(0.006)\end{array}$ & $\begin{array}{c}0.002 \\
(0.113)\end{array}$ \\
\hline Two votes passed & & & $\begin{array}{l}0.022^{* *} \\
(0.010)\end{array}$ & One day later, $t+1$ & $\begin{array}{c}0.007 \\
(0.005)\end{array}$ & $\begin{array}{c}0.011^{*} \\
(0.005)\end{array}$ & $\begin{array}{c}0.173 \\
(0.110)\end{array}$ \\
\hline Three votes passed & & & $\begin{array}{l}0.046^{* * *} \\
(0.017)\end{array}$ & Days $t+2$ to $t+7$ & $\begin{array}{c}0.004 \\
(0.008)\end{array}$ & $\begin{array}{c}-0.000 \\
(0.010)\end{array}$ & $\begin{array}{r}-0.113 \\
(0.106)\end{array}$ \\
\hline Four votes passed & & & $\begin{array}{l}0.046^{* *} \\
(0.022)\end{array}$ & & & & \\
\hline Five votes passed & & & $\begin{array}{l}0.071^{* *} \\
(0.030)\end{array}$ & & & & \\
\hline Six votes passed & & & $\begin{array}{l}0.115^{* * *} \\
(0.031)\end{array}$ & & & & \\
\hline Observations & 11,884 & 11,884 & 11,884 & & 11,884 & 11,884 & 11,884 \\
\hline$R^{2}$ & 0.002 & 0.005 & 0.002 & & 0.005 & 0.007 & 0.007 \\
\hline $\begin{array}{l}\text { Number of } \\
\text { firm-meetings }\end{array}$ & 2,377 & 2,377 & 2,377 & & 2,377 & 2,377 & 2,377 \\
\hline
\end{tabular}

a total of $4.6 \%$ returns, etc.). The effect is significant even when a single proposal is passed, that is, there is no critical number of successful proposals in a meeting necessary to obtain substantial returns.

Columns 4 and 5 allow for a different effect of the two kinds of proposals: the set of antitakeover provisions included in the G-index and the set of Other proposals. Among these Other (non-G-index) proposals, the ones that fall more frequently around the discontinuity are proposals to increase board independence from management and proposals to expense stock options (see the Appendix). We find that most of the effect is driven by antitakeover proposalsin particular, by proposals to repeal a classified board and to eliminate poison 
pills. This is partly because there are more G-index proposals that fall around the discontinuity, so we can estimate them more precisely. This also reflects the fact that G-index proposals are thought to have a potentially greater impact in insulating managers to pursue their private goals. However, we also find positive, albeit somewhat smaller and less precisely estimated, effects of other kinds of proposals, which have received less attention in the literature.

Finally, we replace abnormal returns with a dummy variable that indicates whether the returns were positive or negative. This estimate ignores the magnitude of abnormal returns but is less sensitive to the presence of outliers. Column 6 shows that, on the day of the vote, G-index proposals that passed by a small margin were $16 \%$ more likely to lead to a positive abnormal return than those that failed by a small margin.

In sum, we find that there is a significant $1.3 \%$ average price reaction to proposals that pass by a small margin relative to those that fail by a small margin. ${ }^{18}$ We argue that the regression discontinuity design allows us to obtain a causal estimate that is not driven by omitted variables or unobserved firm characteristics. In Section IV.C below, we study the long-term effects of these votes to assess the evidence on different possible explanations for the positive price reaction.

\section{A.2. Heterogeneous Effects of Governance Proposals}

The previous section provides an estimate of the average effect of passing a governance proposal. However, it is likely that firms with different characteristics may have different quantitative responses to passing a governance proposal. In this section, we study whether the effect of passing a governance proposal is different in different types of firms and when governance provisions matter more.

One would expect that firms with large institutional shareholders (who are among the most active ones) might respond differently from firms with low institutional ownership. Column 1 of Table VI reproduces the analysis of Table $\mathrm{V}$, restricting the sample to firms with above-median concentration of the top five institutional owners. We find that they respond more to passing a provision than firms with more dispersed ownership. In particular, column 1 of Table VI shows that passing a G-index shareholder proposal in concentrated-ownership firms elicits a $2.1 \%$ abnormal return on the day of the meeting, with a further cumulative return of $2.1 \%$ in the 7 days after the meeting. The cumulative effect after 1 week in firms with concentrated ownership is 1.76 times the effect for the whole sample. This may reflect that these firms are more closely monitored and therefore the proposal is more likely to be implemented. It may also reflect that the value of these provisions is higher for these firms, suggesting that governance proposals and monitoring are complements. In column 2 , we

\footnotetext{
18 This is a large and significant effect, in contrast with the generally small or insignificant results found when using the mailing date as an event study (see Gillan and Starks (2000), Thomas and Cotter (2007)).
} 


\section{Table VI}

\section{Abnormal Returns and Firm Heterogeneity}

This table presents the effect of passing a proposal on abnormal returns on the meeting date $(t)$ and on the day after $(t+1)$ and the cumulative effect from $t+2$ to $t+7$ for different subsamples of firms. The dependent variables in all columns are abnormal returns computed using the Fama-French and momentum factors from Carhart (1997). Column 1 includes firms with above-median ownership concentration (percentage controlled by the top five institutional owners); column 2 includes firms with 10 or more antitakeover provisions (above-median G-index) before the meeting; column 3 includes firms with above-median R\&D/assets. Columns 1 to 4 allow for a separate effect of antitakeover proposals (labeled as G-index proposals) and Other governance proposals. Column 5 uses the whole sample and allows for a separate effect of proposals by individual and institutional/activist shareholders. The specification in all columns is given by equation (7). All columns control for year fixed effects, firm-meeting fixed effects, and distance-to-the-election effects; standard errors in parentheses are clustered by firm. Significance at the 10\%, 5\%, and $1 \%$ levels is indicated by ${ }^{*}, * *$, and $* * *$, respectively.

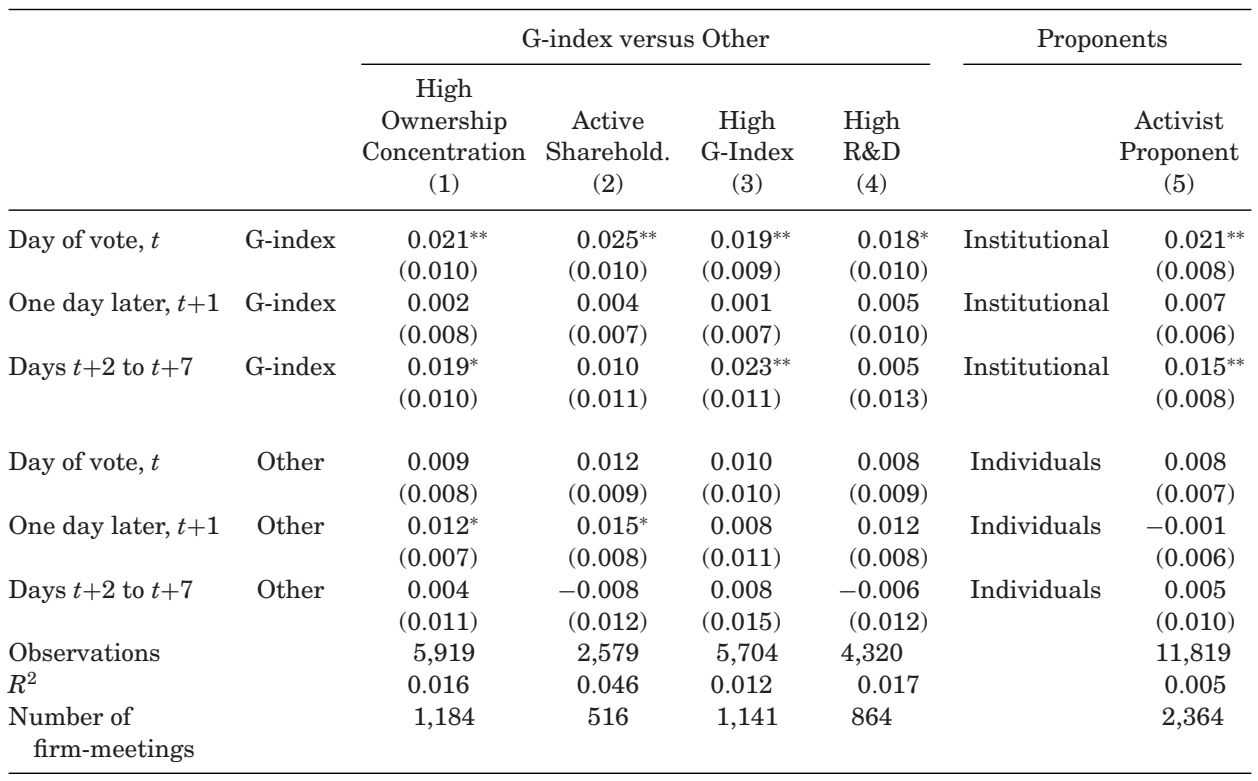

restrict the sample to firms that have been exposed to some degree of activist shareholder pressure. We proxy for shareholder pressure using the number of prior shareholder proposals (i.e., had two or more shareholder-sponsored proposals in the previous two meetings) and find that, in those firms, the effect of passing a G-index proposal is quite high at $2.5 \%$ on the day of the meeting.

We also analyze whether the identity of the proponent is related to the price response to passing a proposal. Some proposals are introduced by wellestablished activist funds or institutional shareholders, while others are put forth by individuals. We might expect larger effects for institutional activists' proposals if they more accurately reflect the needs of the firm and are also more likely to be implemented. Column 5 separately evaluates the effect of passing for proposals by two different groups of proponents: proposals by individuals 
(which constitute around 50\% of the sample) and proposals by institutional activists (these include pension funds, investment funds, companies, and other institutional shareholders). We find that institutional activists' proposals have higher effects, with an abnormal return of $2.1 \%$ on the day of the vote and a further $2.2 \%$ over the following 6 days. For individual proponents, the cumulative effect after 1 week is just $1.1 \%$, and it is not statistically different from zero.

It is also important to determine if there is a critical number of provisions that shield the firm against external discipline. The value of removing an antitakeover provision may be different in firms with many provisions in place relative to those with few, which are already relatively unprotected. Column 3 shows the effect of passing a proposal for firms with more than 10 (median) G-index provisions in place on the day of the meeting. We find that those firms benefit more from the removal of takeover barriers. In particular, passing a G-index shareholder proposal yields a $1.9 \%$ abnormal return on the day of the vote and a further $2.4 \%$ abnormal return over the following 7 days. The cumulative effect after 1 week is $6.6 \%$, that is, 2.64 times the effect for the whole sample. Antitakeover provisions seem to be more effective when bundled together with many others. In contrast, when firms are already relatively unprotected from takeovers, dropping a further provision has a more modest impact on governance.

The previous analysis shows that, on average, passing a proposal that improves shareholder rights increases shareholder value. However, it is possible that excessive shareholder rights could lead managers to focus excessively on the short run at the expense of the long run (Stein (1988)). If this were the case, firms in which long-run investments are important might respond negatively to these governance proposals. We proxy for the long-term nature of firms' investment by their R\&D expenditures. Column 4 estimates our basic model for firms with an above-median R\&D-to-assets ratio prior to the meeting. We find that the effect for these firms (1.8\%) is, if anything, larger than the result for the whole sample (1.3\%), indicating that there is no different response regarding this dimension of long-run investments. The change in abnormal returns due to changes in the governance structure is also positive for these firms.

The regression discontinuity estimate is the weighted average effect across all firms and proposals, where more weight is given to those votes in which a close election was expected (Lee and Lemieux (2010)). In our case, as we mention earlier, the elimination of staggered boards and poison pills represents $68 \%$ of G-index proposals falling around the discontinuity, implying that those proposals have a bigger weight in the identification. In terms of how much one can extrapolate the results of our analysis to other firms, one must take into account the fact that, within listed firms, those that are larger, less profitable, and have a higher level of institutional ownership tend to be targeted by shareholder proposals more often (Karpoff, Malatesta, and Walkling (1996), 
Romano (2001)). ${ }^{19}$ However, within the set of firms that are the target of a proposal, we know from Section III that there are no systematic differences between firms on either side of the threshold, which means there is no evidence of selection into treatment.

\section{A.3. Implementation and the Probability of Passing Future Proposals}

Ertimur, Ferri, and Stubben (2010) show that the average probability that a proposal that passes will be implemented is $31.1 \%$. For proposals that are closer to the threshold, the probability of implementation after passing increases by $20.7 \% .^{20}$ While data on whether each proposal in our sample was implemented are not publicly available, we know how the value of the G-index changes over time for most firms in our sample. The G-index is the number of antitakeover provisions in place at a point in time. We can evaluate how it responds to the passage of a provision at the discontinuity. This serves as a proxy for the net effect on implementation of passing a proposal that incorporates not only the direct effect of passing the particular issue voted on, but also effects on other proposals being passed and implemented-both contemporaneously and in the future. Column 1 of Table VII shows the effect of passing a governance proposal on the G-index. The index is available only every 2 years. Hence, the first coefficient is the effect on the first year available after the focal meeting (this can be between 1 and 2 years after the meeting, depending on when the vote occurred relative to the G-index years), and the second coefficient is 2 years later, etc. We find that the probability of implementation increases discretely around the discontinuity. Thus, proposals that pass by a small margin are substantially more likely to be implemented relative to those that fail. Passing a proposal reduces the G-index by 0.313 , which we interpret as a $31.3 \%$ probability of removing an antitakeover provision within 2 years. That number grows in subsequent years, and within 4 years the probability is $50 \%$. This indicates, among other things, that when a proposal is passed but not implemented, shareholders are likely to propose it again. ${ }^{21}$

\footnotetext{
${ }^{19}$ In the Internet Appendix, we display firm characteristics across different samples. We see that the sample of firms with close-call votes is relatively similar to the S\&P 1500: book-tomarket, return on equity, and cash flow over assets are not statistically different. While differences in return on assets and capital expenditures are statistically significant, they are economically small, at $0.8 \%$ and $0.3 \%$, respectively. In addition, in the Internet Appendix we show that firms with observations around the discontinuity are not "extreme" observations, but rather firms with average characteristics in terms of institutional ownership and Tobin's $Q$.

${ }^{20}$ They estimate that the probability of implementation from proposals that obtain 50\% to $60 \%$ of the vote in favor is $23.9 \%$. The probability that a proposal that failed will be implemented is $3.2 \%$. We obtain $20.7 \%$ as the difference between the two. See Table I, panel D and footnote 9 in Ertimur, Ferri, and Stubben (2010).

${ }^{21}$ Passing a governance proposal in a given meeting is also likely to affect the probability of submitting and passing other proposals in the future. In an earlier version, we estimate these dynamic effects in our data and find that passing G-index proposals makes it more likely that other proposals will be passed in the future (unreported).
} 


\section{Table VII}

\section{Effect of Passing a Governance Proposal on the G-index}

Column 1 shows the effect of passing a governance proposal on the number of antitakeover provisions in place at the firm (the G-index). The index is provided by Riskmetrics every 2 years. The first coefficient (Year of vote, $t$ ) is the effect of passing a proposal on the G-index for the first year available in Riskmetrics that is at least 6 months after the meeting; the second coefficient is the effect 2 years after that, etc. Column 2 allows for six different dummy variables to capture the number of proposals (one to six) that passed at the meeting. The specification in all columns is given by equation (7). All columns control for year fixed effects, firm-meeting fixed effects, and distance-to-the-election effects; standard errors are clustered by firm. Significance at the 10\%, 5\%, and $1 \%$ levels is indicated by ${ }^{*},{ }^{* *}$, and ${ }^{* * *}$, respectively.

\begin{tabular}{lcc}
\hline & \multicolumn{2}{c}{ G-index } \\
\cline { 2 - 3 } & $(1)$ & $(2)$ \\
\hline Year of vote, $t$ & $-0.313^{* * *}$ & $-0.329^{* *}$ \\
Two years later, $t+2$ & $(0.102)$ & $(0.149)$ \\
Four years later, $t+4$ & $-0.329^{* *}$ & $-0.505^{* *}$ \\
& $(0.150)$ & $(0.228)$ \\
Six years later, $t+6$ & $-0.503^{* *}$ & -0.511 \\
Year of vote, $t$ & $(0.229)$ & $(0.389)$ \\
One vote passed & -0.507 & $-0.336^{* * *}$ \\
Two votes passed & $(0.389)$ & $(0.108)$ \\
Three votes passed & & $-0.581^{* * *}$ \\
Four votes passed & & $(0.217)$ \\
Five votes passed & & $-0.744^{* *}$ \\
Number of firm-meetings & & $(0.318)$ \\
& & $-1.828^{* * *}$ \\
& & $(0.589)$ \\
& & $-2.393^{* * *}$
\end{tabular}

\section{B. The Value of a Governance Proposal}

In the previous section, we find that passing a provision increased shareholders' returns on the day of the vote by $1.3 \%$. This is our estimate of $Z$, as defined in Section I.B. However, the observed abnormal return does not fully reflect the value from implementation; rather, it corresponds to the change in the expectation of the proposal being implemented and the additional effect on the submission and implementation of future governance proposals. In order to recover the actual value of a proposal ( $\bar{W}$ ) using expression (2), we need to know (i) the probability that the provision will be implemented if passed, and (ii) the probability that other proposals will be passed and implemented in the future. 
We use the G-index results from Table VII as a proxy for implementation to estimate the value of the proposal to the firm. We show that passing a proposal reduces the number of G-index provisions by 0.31 . We also find that 2 years later, the probability of passing and implementing is $1.6 \%$ higher $\left(p_{t+2}^{p}=0.329-0.313\right)$, and 2 years after that, it is $17.4 \%$ higher $\left(p_{t+4}^{p}=0.503-0.329\right)$, etc. With these probabilities in hand and assuming a discount rate of 5\%, we can use expression (1) to recover the value of a provision to the firm. We estimate that one provision generates an increase of $2.8 \%$ in market value. This is a lower bound for the effect of implementing a governance proposal that only takes into account the 1-day market reaction. Using the less conservative 1-week cumulative returns as our estimate for the market response (2.4\%) would imply a value of implementing one proposal of up to $5.1 \%$. Solving for $Z$ in expression (1), one can also show that two-thirds of the effect is due to contemporaneous factors and one-third to dynamic considerations. ${ }^{22}$

A 2.8\% increase in shareholder value per provision translates into approximately U.S.\$600 million for the average firm in the sample (average market value is U.S. $\$ 22,400$ million in 1996 U.S. dollars). This is an economically sizeable effect, especially when we consider the fact that firms often drop several provisions in subsequent meetings. Dropping 2.5 provisions (one standard deviation of the G-index in the sample) translates into a nonnegligible predicted increase in market value of $7 \%$.

These estimates can be benchmarked against the $8.5 \%$ annualized return that Gompers, Ishii, and Metrick (2003) report when going long on the democratic portfolio and short on the dictatorship portfolio over the 1990 to 1998 period. Their result requires the strong assumption that the value of good governance was not fully understood in 1990 (otherwise the initial prices of both portfolios should have already reflected the value of governance) and that it was at least partially discovered during this period, either explicitly or implicitly, by observing the performance of different firms. Even under the assumption that the importance of antitakeover provisions was fully discovered between 1990 and 1998, using our results we would have only predicted an annualized return between $2.6 \%$ and $4.3 \%{ }^{23}$

\section{Long-Run Effects of Governance}

In this final section, we evaluate the effect of passing a governance proposal on long-term firm outcomes. Evaluating these real effects is important for determining why the firm's market value increases following an improvement in shareholder rights and, in particular, following the removal of antitakeover

\footnotetext{
22 The abnormal return of $1.3 \%$ on the day of the vote can be decomposed, using equation (1), into $0.86 \%$ due to changes in governance within 1 year of the vote and $0.44 \%$ due to subsequent changes.

${ }^{23}$ The difference in average provisions between both portfolios is 9.4 . The $2.6 \%$ return is obtained using our preferred (most conservative) estimate of $2.8 \%$ per provision. This implies a $26.3 \%$ return over 9 years. The $4.3 \%$ is obtained using the full weekly returns with an implied value of a provision of $5.15 \%$.
} 
provisions. The increase in market value could simply reflect that the increased probability of a takeover may lead to a takeover premium. It could also result from an improvement in internal governance and managerial discipline. ${ }^{24}$ This would be the case if weak shareholder rights provided substantial protective power to standing managers (e.g., by insulating them from the takeover market), causing additional agency costs in the form of inefficient investments, reduced operational efficiency, and/or private benefits.

All regressions in Table VIII use the empirical model in expression (7) to estimate the effect of passing a governance proposal on a number of long-term outcomes and to distinguish between the effects of antitakeover and Other proposals. $^{25}$ Columns 1, 2, and 3 examine, respectively, whether the number of acquisitions made by a firm, the growth of capital expenditures, and the bookto-market ratio change significantly in the years following the improvement in shareholder rights. ${ }^{26}$ One way in which improved governance can affect performance is through the reduction in unnecessary acquisitions, investments, and capital-expenditures growth. We compute the number and value of firm acquisitions from the SDC database, which records all transactions of at least $5 \%$ of market value. We find that removing an antitakeover provision reduces the number of acquisitions made in the years following the vote (column 1). This effect is long-lived and exhibits interesting dynamics. The number falls by 0.03 the year after the vote, 0.17 two years later, and 0.18 three years later (only this last coefficient is significant though). ${ }^{27}$ Column 2 shows that the growth of capital expenditures also seems to decline after a vote to eliminate G-index provisions. These results suggest a less aggressive growth policy for better-governed firms and give support to empire building, excessive size, and free cash flow problems as manifestations of poor governance. For other types of provisions the effect is reversed, and capital expenditures actually increase a few years after the vote, but this is subject to the limitations of the data for those proposals at long durations mentioned earlier. Finally, we find some long-term performance improvements following these exogenous changes in governance. Column 3 of Table VIII shows that the book-to-market ratio of the

\footnotetext{
${ }^{24}$ We tested directly (unreported) whether the proposals had an effect on the probability of being taken over using firm delisting information from CRSP. Firms that pass more proposals are more likely to be acquired but we find no significant difference around the discontinuity in takeover probabilities. However, conclusively establishing this result would require a separate analysis given the relatively low frequency of such events and given that the endogenous change in manager behavior will reduce observed takeover probabilities.

25 To avoid the effect of outliers, for each column of Table VIII we restrict the sample to firmvotes that do not have any observation in the top or bottom $5 \%$ of the distribution of the dependent variable. The results are not sensitive to this particular outlier cutoff but are sensitive to the inclusion of outliers.

${ }^{26}$ Since we are looking at effects up to 4 years after the vote, we cannot estimate the long-run effects for proposals at the end of the sample. This is particularly problematic for Other proposals because they are more frequent toward the end of the sample. Our very demanding identification in terms of data requirements (fixed effects, clustering, discontinuity) is bound to yield larger standard errors.

${ }^{27}$ We find a similar pattern for the value of these acquisitions (see the Internet Appendix).
} 


\section{Table VIII}

\section{Long-Run Effects of Governance Proposals}

This table presents the effect of passing a governance proposal on firm long-term outcomes. The specification in all columns is given by equation (7). All columns allow for a separate effect of antitakeover proposals (labeled as G-index proposals) and Other governance proposals. The dependent variables are: the number of acquisitions in column 1, the growth rate of capital expenditures in column 2, and book-to-market value of the firm in column 3. See notes to Table II for further sources and definitions. Standard errors in parentheses are clustered by firm. Significance at the $10 \%, 5 \%$, and $1 \%$ levels is indicated by ${ }^{*}, * *$, and ${ }^{* * *}$, respectively.

\begin{tabular}{|c|c|c|c|c|}
\hline & & $\begin{array}{c}\text { Acquisitions Count } \\
\text { (1) }\end{array}$ & $\begin{array}{c}\text { Capex Growth } \\
\text { (2) }\end{array}$ & $\begin{array}{c}\text { Book-to-Market } \\
\text { (3) }\end{array}$ \\
\hline Year of meeting, $t$ & G-index & $\begin{array}{l}-0.00102 \\
(0.120)\end{array}$ & $\begin{array}{c}-0.0797 \\
(0.0541)\end{array}$ & $\begin{array}{r}-0.0172 \\
(0.0270)\end{array}$ \\
\hline One year later, $t+1$ & G-index & $\begin{array}{c}-0.0305 \\
(0.102)\end{array}$ & $\begin{array}{r}-0.117^{* *} \\
(0.0577)\end{array}$ & $\begin{array}{r}-0.0255 \\
(0.0337)\end{array}$ \\
\hline Two years later, $t+2$ & G-index & $\begin{array}{r}-0.166 \\
(0.109)\end{array}$ & $\begin{array}{c}-0.0411 \\
(0.0664)\end{array}$ & $\begin{array}{r}-0.0648^{*} \\
(0.0342)\end{array}$ \\
\hline Three years later, $t+3$ & G-index & $\begin{array}{r}-0.180^{*} \\
(0.108)\end{array}$ & $\begin{array}{c}-0.00382 \\
(0.0671)\end{array}$ & $\begin{array}{c}-0.0970^{* * *} \\
(0.0362)\end{array}$ \\
\hline Four years later, $t+4$ & G-index & $\begin{array}{c}0.166 \\
(0.134)\end{array}$ & $\begin{array}{c}-0.0922 \\
(0.0648)\end{array}$ & $\begin{array}{c}-0.0941^{* *} \\
(0.0419)\end{array}$ \\
\hline Year of meeting, $t$ & Other & $\begin{array}{c}0.0384 \\
(0.122)\end{array}$ & $\begin{array}{l}0.114 \\
(0.0832)\end{array}$ & $\begin{array}{c}-0.0607^{* *} \\
(0.0254)\end{array}$ \\
\hline One year later, $t+1$ & Other & $\begin{array}{c}0.135 \\
(0.132)\end{array}$ & $\begin{array}{c}0.0161 \\
(0.106)\end{array}$ & $\begin{array}{r}-0.107^{* *} \\
(0.0436)\end{array}$ \\
\hline Two years later, $t+2$ & Other & $\begin{array}{c}0.316 \\
(0.223)\end{array}$ & $\begin{array}{c}0.157 \\
(0.103)\end{array}$ & $\begin{array}{c}0.00972 \\
(0.0724)\end{array}$ \\
\hline Three years later, $t+3$ & Other & $\begin{array}{c}0.248 \\
(0.214)\end{array}$ & $\begin{array}{l}0.464^{* * *} \\
(0.144)\end{array}$ & $\begin{array}{c}-0.0266 \\
(0.0447)\end{array}$ \\
\hline Four years later, $t+4$ & Other & $\begin{array}{l}0.500^{* *} \\
(0.253)\end{array}$ & $\begin{array}{l}0.664^{* *} \\
(0.257)\end{array}$ & $\begin{array}{c}0.0444 \\
(0.101)\end{array}$ \\
\hline Observations & & 11,384 & 6,501 & 9,120 \\
\hline$R^{2}$ & & 0.022 & 0.027 & 0.024 \\
\hline Number of firm-meetings & 1,797 & 1,524 & 1,817 & \\
\hline
\end{tabular}

firm falls significantly as a result of passing the governance proposals (both G-index and Other). Given that the abnormal returns seem to be linear in the number of provisions passed (Table V, column 3), we also check whether the real effects reported in this section also follow a linear pattern. The results (reported in the Internet Appendix) show a linear pattern of real effects. This is further evidence that links both effects. The Internet Appendix provides additional long-term results.

Overall, we find that, as a result of the removal of antitakeover provisions, acquisitions and capital expenditures fall and firm valuation increases in the long-run, which provides evidence of dynamic effects of governance well beyond the year the proposal passed. In contrast, there is little effect on earnings (see also the Internet Appendix). Although some of these effects are imprecisely estimated, this suggests that the abnormal returns that we identify in 
earlier sections as a result of governance improvements lead to actual changes in managers' actions. Furthermore, if one is willing to interpret the marginal acquisitions and capital expenditures as value-destroying and a way in which managers extract private benefits (e.g., through empire building), then our evidence suggests that corporate governance proposals that remove antitakeover provisions increase shareholder value through disciplining management and a reduction in agency costs.

\section{Conclusion}

In this paper, we present novel evidence on the causal effect of corporate governance provisions on firms' market value and long-term performance. We adapt the regression discontinuity design to the analysis of event studies and apply it to the outcomes of votes on governance proposals in shareholder meetings. Firms that pass a proposal by a close margin are ex ante similar to those that reject it by a close margin. Hence, passing a provision is "locally" exogenous, leading to a discrete increase in the probability of implementation. This approach provides a causal estimate and overcomes the endogeneity problems that have affected the literature thus far. Our empirical strategy allows us to recover an estimate of the effect of governance even if, prior to the vote, the market had already incorporated the probability of passing the shareholder proposal into stock prices. This is because proposals that fell around the majority threshold were, ex ante, the most uncertain, in which case investors could not perfectly predict whether they would pass. It is for these proposals that we are able to observe a price reaction. This strategy allows us to interpret our results as causal, overcoming the limitations of the existing literature.

We show that, on average, the market reacts to the passage of a governancerelated shareholder proposal with positive abnormal returns of around $1.3 \%$ on the day of the vote. This reflects an increase in market value of $2.8 \%$ per implemented proposal. We identify some heterogeneity of this reaction, with the effect being more pronounced among firms with concentrated ownership, high preexisting antitakeover provisions, high R\&D expenditures, and stronger shareholder pressure, and for proposals made by institutional shareholders rather than by individuals. However, while positive, the magnitude of our estimated effects is between one-third and one-half of the estimates in Gompers, Ishii, and Metrick (2003).

Firm behavior also changes with new governance structures. Dropping antitakeover provisions leads to lower investments and fewer acquisitions. Finally, the long-term performance of the firm, measured using Tobin's $Q$ or bookto-market ratios, improves after 2 or 3 years when antitakeover provisions are dropped; nevertheless, we find modest results with respect to return on equity.

Our analysis also uncovers interesting dynamic effects. Passing a governance proposal affects the chance of dropping a provision both now and in the future. In terms of shareholder returns, two-thirds of the effect is associated with contemporaneous provision changes and one-third with future ones. The real 
effects associated with governance changes are also dynamic, with some effects materializing up to 4 years after a proposal passes.

As a whole, our results suggest that changing the internal corporate governance in targeted firms is rewarded by the market-with more pronounced effects for proposals to remove antitakeover provisions. These changes also yield performance improvements in the long run. The evidence indicates that the channels behind these improvements include more conservative investment and acquisition policies.

A better understanding of the effect of governance provisions and the magnitude of the agency problem is crucial to guiding the public debate on the adequacy of implementing and regulating corporate governance. Our results provide causal evidence that the value of improving governance inside firms is sizeable. Our results also shed light on the potential role of shareholder activism in improving the governance of firms and creating value. In particular, our evidence suggests that shareholder activism and improved democracy inside firms can have large positive effects on shareholder value.

\section{Appendix}

Description of All Shareholder Proposals (Rismetrics 1997 to 2007)

\begin{tabular}{|c|c|c|c|c|c|c|}
\hline \multirow[b]{2}{*}{ Type } & \multirow[b]{2}{*}{ Description Proposal } & \multirow[b]{2}{*}{ Observations } & \multirow[b]{2}{*}{ Mean Vote For } & \multicolumn{3}{|c|}{ Discontinuity } \\
\hline & & & & $\#-5,+5$ & $\#-10,10$ & Frequ. \\
\hline \multirow[t]{3}{*}{ Audit } & Limit consulting by auditors & 59 & 20.1 & 2 & 5 & \\
\hline & Shareholder approval of auditors & 7 & 48.0 & 2 & 3 & \\
\hline & Rotate auditor & 2 & 5.3 & 0 & 0 & 68 \\
\hline \multirow[t]{14}{*}{ Board } & Separate chairman/CEO & 224 & 28.2 & 15 & 33 & \\
\hline & Majority independent directors & 89 & 26.1 & 5 & 9 & \\
\hline & $\begin{array}{l}\text { Commit to/report on board } \\
\text { diversity }\end{array}$ & 60 & 16.7 & 0 & 1 & \\
\hline & Limit director tenure & 54 & 6.3 & 0 & 1 & \\
\hline & $\begin{array}{l}\text { Independent nominating } \\
\text { committee }\end{array}$ & 24 & 25.7 & 2 & 2 & \\
\hline & $\begin{array}{l}\text { Increase key committee } \\
\text { independence }\end{array}$ & 15 & 19.0 & 0 & 0 & \\
\hline & $\begin{array}{l}\text { Allow union/employee reps. on the } \\
\text { board }\end{array}$ & 11 & 7.7 & 0 & 0 & \\
\hline & $\begin{array}{l}\text { Increase compensation committee } \\
\text { independence }\end{array}$ & 10 & 35.1 & 3 & 4 & \\
\hline & $\begin{array}{l}\text { Minimum director stock } \\
\text { ownership }\end{array}$ & 9 & 7.6 & 0 & 0 & \\
\hline & $\begin{array}{l}\text { Independent compensation } \\
\text { committee }\end{array}$ & 7 & 18.8 & 0 & 0 & \\
\hline & Lead director & 6 & 24.4 & 0 & 1 & \\
\hline & Shareholder advisory committee & 4 & 10.2 & 0 & 0 & \\
\hline & $\begin{array}{l}\text { Increase audit committee } \\
\text { independence }\end{array}$ & 4 & 19.5 & 0 & 0 & \\
\hline & Create nominating committee & 3 & 24.7 & 0 & 0 & 520 \\
\hline
\end{tabular}




\section{Appendix-Continued}

\begin{tabular}{|c|c|c|c|c|c|c|}
\hline \multirow[b]{2}{*}{ Type } & \multirow[b]{2}{*}{ Description Proposal } & \multirow[b]{2}{*}{ Observations } & \multirow[b]{2}{*}{ Mean Vote For } & \multicolumn{3}{|c|}{ Discontinuity } \\
\hline & & & & $\#-5,+5$ & $\#-10,10$ & Frequ. \\
\hline \multirow[t]{18}{*}{ Compensation } & $\begin{array}{l}\text { Link pay to performance/ } \\
\text { recoup bonuses }\end{array}$ & 371 & 16.0 & 12 & 21 & \\
\hline & $\begin{array}{l}\text { Award performance-based } \\
\text { stock options }\end{array}$ & 114 & 23.6 & 6 & 17 & \\
\hline & Expense stock options & 112 & 50.1 & 39 & 68 & \\
\hline & $\begin{array}{l}\text { Link executive pay to social } \\
\text { criteria }\end{array}$ & 109 & 8.2 & 0 & 0 & \\
\hline & $\begin{array}{l}\text { Disclose executive } \\
\text { compensation }\end{array}$ & 59 & 11.5 & 1 & 3 & \\
\hline & $\begin{array}{l}\text { Advisory vote on } \\
\text { compensation }\end{array}$ & 53 & 41.5 & 14 & 33 & \\
\hline & Misc compensation & 42 & 25.6 & 3 & 10 & \\
\hline & Cap executive pay & 35 & 8.0 & 0 & 0 & \\
\hline & $\begin{array}{l}\text { Add performance criteria to } \\
\text { equity-based awards }\end{array}$ & 31 & 34.4 & 6 & 12 & \\
\hline & $\begin{array}{l}\text { Restrict director } \\
\text { compensation }\end{array}$ & 29 & 9.6 & 0 & 0 & \\
\hline & $\begin{array}{l}\text { Approve/disclose/limit } \\
\text { SERPs }\end{array}$ & 24 & 35.6 & 5 & 7 & \\
\hline & Pay directors in stock & 23 & 11.8 & 0 & 0 & \\
\hline & $\begin{array}{l}\text { Restrict nonemployee } \\
\text { director pensions }\end{array}$ & 14 & 31.1 & 0 & 1 & \\
\hline & $\begin{array}{l}\text { Pension fund surplus } \\
\text { reporting }\end{array}$ & 14 & 33.6 & 0 & 4 & \\
\hline & $\begin{array}{l}\text { Require equity awards to } \\
\text { be held }\end{array}$ & 12 & 27.5 & 0 & 0 & \\
\hline & $\begin{array}{l}\text { No repricing underwater } \\
\text { stock option }\end{array}$ & 11 & 31.6 & 3 & 4 & \\
\hline & $\begin{array}{l}\text { Approve executive } \\
\text { compensation }\end{array}$ & 4 & 31.3 & 0 & 1 & \\
\hline & $\begin{array}{l}\text { Hire independent } \\
\text { compensation consultant }\end{array}$ & 4 & 39.9 & 1 & 2 & 1,061 \\
\hline \multicolumn{7}{|l|}{ G-Index } \\
\hline G_Delay & Repeal classified board & 549 & 57.5 & 116 & 219 & \\
\hline G_Other & Redeem or vote poison pill & 355 & 57.7 & 77 & 132 & \\
\hline G_Voting & Cumulative voting & 273 & 31.5 & 22 & 49 & \\
\hline G_Protection & $\begin{array}{l}\text { Vote on future golden } \\
\text { parachutes }\end{array}$ & 152 & 44.4 & 19 & 56 & \\
\hline G_Voting & $\begin{array}{l}\text { Eliminate supermajority } \\
\text { provision }\end{array}$ & 109 & 62.7 & 16 & 32 & \\
\hline G_Other & $\begin{array}{l}\text { Remove antitakeover } \\
\text { provisions \& other }\end{array}$ & 42 & 41.4 & 2 & 8 & \\
\hline G_Voting & Confidential voting & 39 & 52.7 & 7 & 16 & \\
\hline G_Delay & $\begin{array}{l}\text { Shareholders may call } \\
\text { special meeting }\end{array}$ & 25 & 56.5 & 3 & 8 & \\
\hline G_Protection & Compensation plans & 6 & 18.7 & 0 & 0 & \\
\hline G_Other & Adopt antigreenmail & 3 & 30.7 & 0 & 1 & \\
\hline G_Protection & Maximum director liability & 3 & 15.5 & 0 & 0 & \\
\hline G_Voting & Require only majority vote & 2 & 50.1 & 0 & 2 & 1,558 \\
\hline
\end{tabular}


Appendix-Continued

\begin{tabular}{|c|c|c|c|c|c|c|}
\hline \multirow{2}{*}{ Type } & \multirow[b]{2}{*}{ Description Proposal } & \multirow[b]{2}{*}{ Observations } & \multirow[b]{2}{*}{ Mean Vote For } & \multicolumn{3}{|c|}{ Discontinuity } \\
\hline & & & & $\#-5,+5$ & $\#-10,10$ & Frequ. \\
\hline \multirow[t]{14}{*}{ Other } & Study sell company & 162 & 15.8 & 2 & 7 & \\
\hline & Miscellanea & 138 & 14.5 & 3 & 6 & \\
\hline & Double board nominees & 43 & 8.1 & 0 & 0 & \\
\hline & $\begin{array}{l}\text { Change annual meeting } \\
\text { location }\end{array}$ & 20 & 6.0 & 0 & 0 & \\
\hline & Reincorporate to U.S. state & 15 & 25.5 & 0 & 2 & \\
\hline & $\begin{array}{l}\text { Change annual meeting } \\
\text { date }\end{array}$ & 12 & 4.4 & 0 & 0 & \\
\hline & $\begin{array}{l}\text { Affirm political } \\
\text { nonpartisanship }\end{array}$ & 8 & 7.2 & 0 & 0 & \\
\hline & $\begin{array}{l}\text { Vote on targeted share } \\
\text { placement }\end{array}$ & 4 & 42.4 & 0 & 3 & \\
\hline & Issue postmeeting report & 3 & 5.5 & 0 & 0 & \\
\hline & $\begin{array}{l}\text { Opt out of state takeover } \\
\text { statute }\end{array}$ & 3 & 46.6 & 0 & 1 & \\
\hline & $\begin{array}{l}\text { Disclose prior government } \\
\text { service }\end{array}$ & 2 & 3.2 & 0 & 0 & \\
\hline & $\begin{array}{l}\text { Improve postmeeting } \\
\text { report }\end{array}$ & 2 & 6.6 & 0 & 0 & \\
\hline & Restore preemptive rights & 1 & 27.5 & 0 & 0 & \\
\hline & $\begin{array}{l}\text { Nominee statement in } \\
\text { proxy }\end{array}$ & 1 & 9.1 & 0 & 0 & 416 \\
\hline \multirow[t]{5}{*}{ Voting } & $\begin{array}{l}\text { Majority vote to elect } \\
\text { directors }\end{array}$ & 206 & 45.9 & 56 & 115 & \\
\hline & $\begin{array}{l}\text { Majority vote shareholder } \\
\text { committee }\end{array}$ & 128 & 15.9 & 8 & 9 & \\
\hline & No discretionary voting & 11 & 14.8 & 0 & 0 & \\
\hline & Counting shareholder votes & 6 & 15.4 & 0 & 0 & \\
\hline & Equal access to proxy & 5 & 22.0 & 1 & 2 & 356 \\
\hline
\end{tabular}

\section{REFERENCES}

Agrawal, Ashwini K., 2008, Corporate governance objectives of labor union shareholders: Evidence from proxy voting, Working Paper FIN-08-006, Stern School of Business, New York University.

Bebchuck, Lucian A., Alma Cohen, and Allen Ferrell, 2004, What matters in corporate governance? Review of Financial Studies 22, 783-827.

Becht, Marco, Patrick Bolton, and Ailsa Röell, 2005, Corporate governance and control, European Corporate Governance Institute Working Paper.

Bertrand, Marianne, and Sendhil Mullainathan, 2003, Enjoying the quiet life? Corporate governance and managerial preferences, Journal of Political Economy 111, 1043-1075.

Brickley, James, Ronald C. Lease, and Clifford W. Smith, Jr., 1988, Ownership structure and voting on antitakeover amendments, Journal of Financial Economics 20, 267-291.

Carhart, Mark M., 1997, On persistence in mutual fund performance, Journal of Finance 52, $57-82$.

Cellini, Stephanie R., Fernando Ferreira, and Jesse Rothstein, 2010, The value of school facility investments: Evidence from a dynamic regression discontinuity design, Quarterly Journal of Economics 125, 215-261.

Comment, Robert G., and William Schwert, 1995, Poison or placebo? Evidence on the deterrence and wealth effects of modern antitakeover measures, Journal of Financial Economics 39, 3-43. 
Core, John E., Wayne R. Guay, and Tjomme O. Rusticus, 2006, Does weak governance cause weak stock returns? An examination of firm operating performance and investors' expectations, Journal of Finance 61, 655-687.

Ertimur, Yonca, Fabrizio Ferri, and Stephen Stubben, 2010, Board of directors' responsiveness to shareholders: Evidence from shareholder proposals, Journal of Corporate Finance 16, 53-72.

Garvey, Gerald T., and Gordon Hanka, 1999, Capital structure and corporate control: The effect of antitakeover statutes on firm leverage, Journal of Finance 54, 519-546.

Gillan, Stuart L., and Laura T. Starks, 2000, Corporate governance proposals and shareholder activism: The role of institutional investors, Journal of Financial Economics 57, 275-305.

Giroud, Xavier, and Holger M. Mueller, 2010, Does corporate governance matter in competitive industries? Journal of Financial Economics 95, 312-331.

Gompers, Paul A., Joy L. Ishii, and Andrew Metrick, 2003, Corporate governance and equity prices, Quarterly Journal of Economics 118, 107-155.

Jensen, Michael C., 1986, Agency costs of free cash flow, corporate finance, and takeovers, The American Economic Review 76, 323-329.

Kadyrzhanova, Dalida, and Matthew Rhodes-Kropf, 2011, Concentrating on governance, Journal of Finance 66, 1649-1685.

Karpoff, Jonathan, Paul Malatesta, and Ralph Walkling, 1996, Corporate governance and shareholder initiatives: Empirical evidence, Journal of Financial Economics 42, 365-395.

Lee, David, 2008, Randomized experiments from nonrandom selection in U.S. house elections, Journal of Econometrics 142, 675-697.

Lee, David, and Thomas Lemieux, 2010, Regression discontinuity designs in economics, Journal of Economic Literature 48, 281-355.

Listokin, Yair, 2008, Management always wins the close ones, American Law and Economics Review 10, 159-184.

McCrary, Justin, 2008, Manipulation of the running variable in the regression discontinuity design: A density test, Journal of Econometrics 142, 698-714.

Romano, Roberta, 2001, Less is more: Making shareholder activism a valuable mechanism of corporate governance, Yale Journal on Regulation 18, 174-251.

Shleifer, Andrei, and Robert W. Vishny, 1997, A survey of corporate governance, Journal of Finance $52,737-783$.

Stein, Jeremy C., 1988, Efficient capital markets, inefficient firms: A model of myopic corporate behavior, Quarterly Journal of Economics 104, 655-669.

Thomas, Randall, and James F. Cotter, 2007, Shareholder proposals in the new millennium: Shareholder support, board response and market reaction, Journal of Corporate Finance 13, 368-391. 